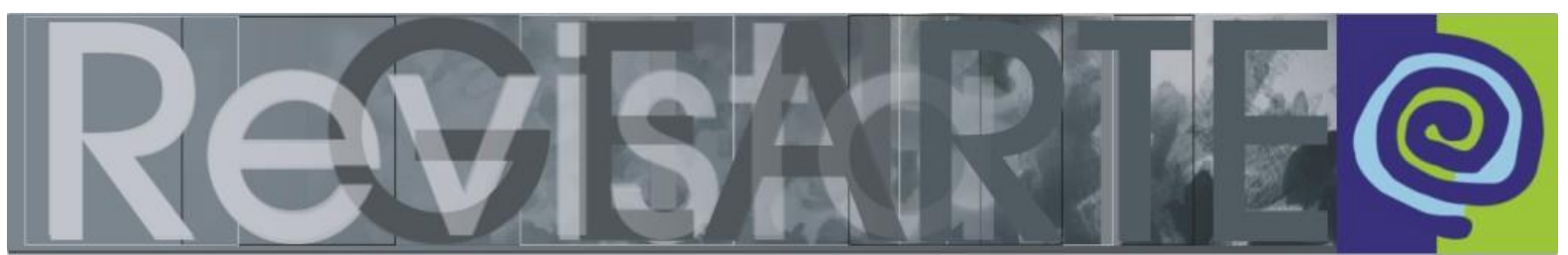

ISSN 2357-9854 | e-ISSN 2596-3198 (online)

\title{
A obra artística fotográfica de Pierre Verger em processos de ensino, aprendizagem e criação em artes no ensino médio
}

\author{
Mariana Brazili \\ (Secretaria de Educação do Estado da Bahia - Salvador/BA, Brasil) \\ Marise Berta de Souza ${ }^{(1)}$ \\ (Universidade Federal da Bahia — UFBA, Salvador/BA, Brasil)
}

\begin{abstract}
RESUMO - A obra artística fotográfica de Pierre Verger em processos de ensino, aprendizagem e criação em artes no ensino médio - Esse trabalho aborda a obra fotográfica de Pierre Verger, na perspectiva da (re)leitura das suas imagens como suporte interpretativo no ensino de artes. A experiência ocorreu em uma turma de escola pública de ensino médio no município de Lauro de Freitas, Bahia, Brasil. Como fio propulsor traz a premissa de Ana Mae Barbosa, na qual é preciso desenvolver nos alunos a consciência política, a desmistificação dos mitos colonizadores e o estudo de movimentos descolonizadores. Analisou-se 30 imagens selecionadas do acervo da Fundação Pierre Verger, cujos critérios de seleção foram figuras humanas e elementos da cultura baiana. A dialética das (re)leituras e da produção autônoma resultou em uma potente intervenção na própria realidade e visão de mundo dos alunos.
\end{abstract}

PALAVRAS-CHAVE

Educação. Pierre Verger. Fotografia. Identidade cultural. Releitura.

ABSTRACT - Pierre Verger's photographic artistic works in processes of art teaching, learning and development at high school environments - This article approaches the photographic work of Pierre Verger, from the perspective of (re)reading his images as an interpretive support in the teaching of arts. The experience took place in a public high school class in the municipality of Lauro de Freitas, Bahia, Brazil. As a propelling thread, it brings the premise of Ana Mae Barbosa, in which it is necessary to develop in students the political conscience, the demystification of colonizing myths and the study of decolonizing movements. We analyzed 30 selected images from the collection of the Pierre Verger Foundation, whose selection criteria were human figures and elements of Bahian culture. The dialectic of (re)readings and autonomous production resulted in a powerful intervention in the students' own reality and worldview.

\section{KEY-WORDS}

Education. Pierre Verger, Photography. Cultural identity. Rereading.

RESUMEN - El trabajo artístico fotográfico de Pierre Verger en los procesos de enseñanza, aprendizaje y creación en las artes de la escuela secundaria - Este trabajo aborda el trabajo fotográfico de Pierre Verger, en la perspectiva de (re)leer sus imágenes como soporte interpretativo en la enseñanza de las artes. La experiencia tuvo lugar en una clase de escuela secundaria pública en el municipio de Lauro de Freitas, Bahía, Brasil. Como hilo conductor, trae la premisa de Ana Mae Barbosa, en la que es necesario desarrollar en los estudiantes la conciencia política, la desmitificación de los mitos colonizadores y el estudio de los movimientos descolonizadores. Se analizaron 30 imágenes seleccionadas de la colección de la Fundación Pierre Verger, cuyos criterios de selección fueron figuras humanas y elementos de la cultura bahiana. La dialéctica de (re) lecturas y producción autónoma resultó en una poderosa intervención en la propia realidad y cosmovisión de los estudiantes.

PALABRAS CLAVE

Educación. Pierre Verger. Fotografía. Identidad cultural. Relectura.

BRAZIL, Mariana; SOUZA, Marise Berta de. A obra artística fotográfica de Pierre Verger 


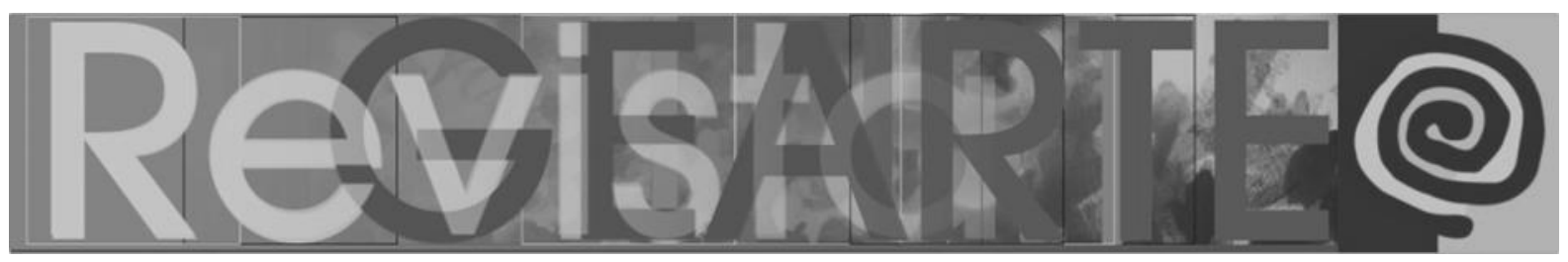

\section{Introdução}

Este trabalho trata de uma experiência de ensino/aprendizagem em artes visuais que propõe a utilização da linguagem fotográfica como um meio de desenvolver o olhar e a criatividade, além de estimular a problematização e o debate para integrar grupos, aguçar a visão e a percepção de mundo, em uma comunidade estudantil do ensino médio.

O trabalho docente em Artes na escola pública brasileira é, sem dúvida, um desafio constante, que passa inevitavelmente pelo enfrentamento necessário à realidade cultural e socioeconômica dos nossos alunos. Mais especificamente no Nordeste do país, e mais ainda no estado da Bahia, essa realidade converge fortemente para a decolonialidade ${ }^{1}$, a identidade cultural e ancestralidade afrodescendente. Colocar em prática o que a lei estabelece nos parece muitas vezes quase impossível, haja vista que as precariedades gerais da escola pública no Brasil potencializam as dificuldades, as quais somam-se o pouco reconhecimento em relação às outras disciplinas preparatórias para exames de conclusão de ciclo escolar e ingresso no ensino superior. Hansen (2017) chama a atenção para outros fatores que têm levado ao desestímulo, tanto professores quanto estudantes, para realizar atividades pedagógicas de qualidade: reduzida carga horária semanal; concentração em uma especialidade ou a falta de professores especialistas; salas de aulas raramente exclusivas para as atividades artísticas, disputadas por outros usos na rotina escolar; falta de materiais e infraestrutura adequados para as atividades propostas; falta de recursos para atividades externas (transportes e ingressos).

Foram esses os principais desafios que motivaram essa pesquisa, somados ao anseio de contribuir de maneira integrada à leitura de imagens, o fazer artístico e ainda contextualizar, no mundo desses adolescentes, os valores ancestrais que eles trazem em si. 


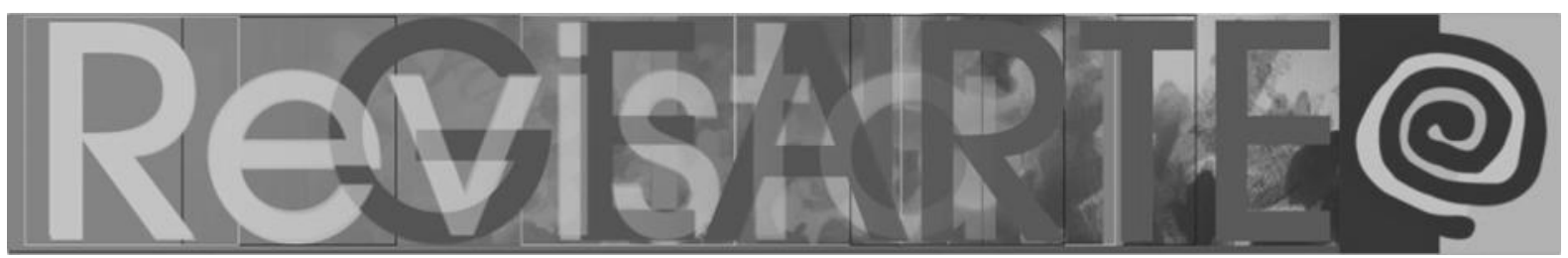

A pesquisa aqui discutida teve como base uma proposta pedagógica desenvolvida no semestre 2019.2, no Colégio Estadual Hermano de Gouveia Neto (CEHGN), unidade escolar estadual (Código Sec:1176364), considerada uma escola de grande porte, com cerca de 1600 alunos. Localiza-se em Lauro de Freitas, município da Região Metropolitana de Salvador, em um bairro de população de baixa renda, na sua maioria afrodescendente. A escola atende às turmas do Ensino Médio e de Educação de Jovens e Adultos (EJA), com uma infraestrutura considerada boa, em construção térrea, com salas de aula conservadas, mobiliário que contempla todos os alunos, sala de artes, sala de informática e sala de vídeos. Como todo colégio da rede estadual de ensino, o mês de novembro é dedicado às atividades artísticas e culturais voltadas para a celebração do Dia da Consciência Negra (20 de novembro), no intuito de resgatar e valorizar a cultura e a identidade negra. No CEHGN, as aulas desse período trabalham nessa temática da consciência negra como eixo integrador de todas as disciplinas.

A população estudantil do ensino médio caracteriza-se por ser adolescentes dentro da faixa etária de 13 a 17 anos. Há turmas com um índice de evasão relativamente alto, com famílias nem sempre estruturadas e alguns em vulnerabilidade e risco social. Boa parte desses adolescentes mora no bairro Quingoma, conhecida comunidade quilombola, antiga zona de engenho do Recôncavo Baiano, localizado a $3 \mathrm{~km}$ de Lauro de Freitas. A turma em foco para esse trabalho foi a do $1^{\circ}$ ano do Ensino Médio (Turma D, matutino), composta de 45 alunos, dos quais permaneceram, até o final do ano, 39.

Como componente curricular Artes no CEHGN trabalha-se o conteúdo Conhecimento e Expressão em Artes Visuais, adequado à formação da professora e conforme a concepção de arte-educação expressa na Proposta Triangular de Ana Mae Barbosa (1995). Concepção essa que foi adotada nos Parâmetros Curriculares Nacionais (PCNs) desde 1997 (BRASIL, 1997), e que tem sido o norte para essa disciplina no país. Nos PCNs fica clara a interação entre a dimensão 


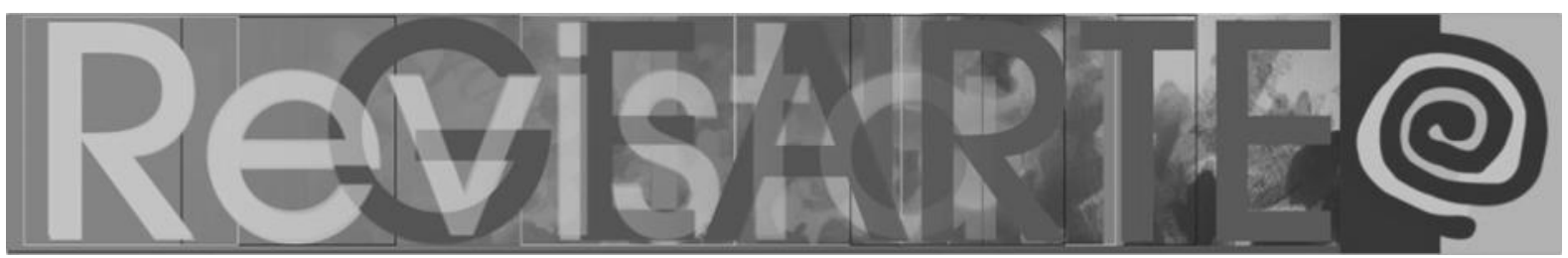

estética e a dimensão política, evidenciando uma maneira de integrar-se à teoria pós-colonialista. O que a torna extremamente relevante, principalmente porque "[...] sendo uma teoria com suas bases fincadas na experiência brasileira, contextualiza politicamente a nossa sociedade e suas desigualdades herdadas de seu processo colonizador" (AZEVEDO e ARAÚJJO, 2015, p. 16).

Em consequência, em 2000, o documento Parâmetros Curriculares Nacionais para o Ensino Médio (PCNEM) trouxe diretrizes de fundamentos estéticos, políticos e éticos organizados sob três consignas: a estética da sensibilidade, a política da igualdade e a ética da identidade (BRASIL-PCNEM I, 2000, p.62), onde os conhecimentos em Artes indicam um significado de apropriação de saberes vinculados à cidadania (BRASIL - PCNEM II, 2000, p.55). Em 2003, a Lei no $10.639^{2}$ incluiu no currículo oficial da rede de ensino brasileira a obrigatoriedade da temática História e Cultura Afro-Brasileira e ainda incluiu o Dia Nacional da Consciência Negra. A lei estabelece claramente que os conteúdos referentes à História e Cultura Afro-Brasileiras serão ministrados no âmbito de todo o currículo escolar, em especial nas áreas de Educação Artística e de Literatura e História Brasileiras.

Nos PCNs, também fica claro que a apropriação de saberes das áreas curriculares busca estabelecer correspondência não apenas entre as formas de comunicação - das quais as artes fazem parte inseparável -, mas também, como evidenciar a importância de todas as linguagens enquanto constituintes dos conhecimentos e das identidades dos alunos, de modo a contemplar as possibilidades artísticas, lúdicas e motoras de conhecer o mundo. A utilização dos códigos que dão suporte às linguagens não visa apenas ao domínio técnico, mas principalmente à competência de desempenho, ao saber usar as linguagens em diferentes situações ou contextos, considerando inclusive os interlocutores (BRASIL-PCNEM, 2000, p. 92). 


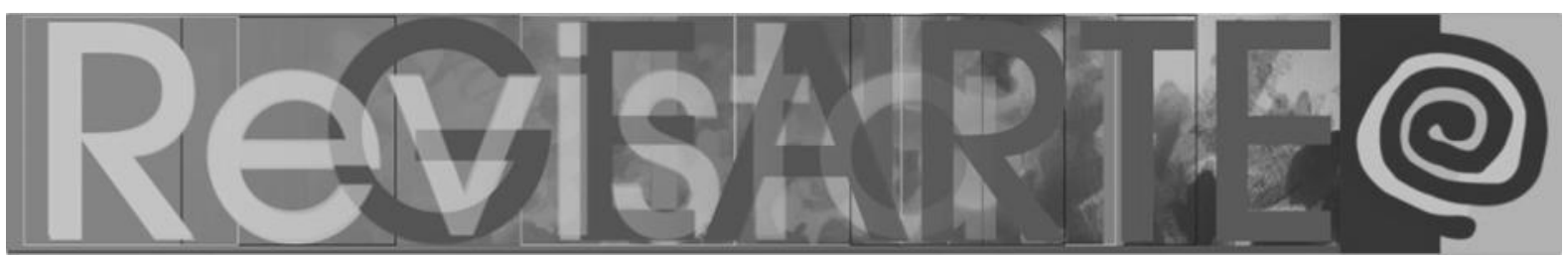

Ao se entender a fotografia como uma linguagem artística, infere-se que esta pode expressar sentimentos e pensamentos que não só contribuem enquanto instrumento capaz de perpetuar e imortalizar momentos, mas como um instrumento de aprendizagem, reflexão e comunicação sobre si e o mundo que nos cerca (BRASIL, 1998, p. 63). Nesse contexto, o desafio neste trabalho foi desenvolver através dessa linguagem, a percepção, a sensibilidade e a criatividade dos alunos no processo de reconhecimento e valorização sociopolítico e histórico do seu espaço de convívio, na escola e fora dela.

Por consequência, fundamenta-se esse trabalho na obra fotográfica de Pierre Verger, selecionada não só por trazer imagens reflexivas das linguagens plásticas visuais, mas, principalmente, imagens representativas da identidade cultural afro-brasileira ambientadas em situações homólogas as que os estudantes vivem no seu cotidiano, resguardados os contextos e temporalidades distintas. Com base nessas premissas e, considerando o perfil do alunado do CEHGN, essa pesquisa buscou trazer a obra fotográfica de Verger, como um suporte interpretativo no processo de ensino-aprendizagem de artes no ensino médio, na perspectiva de uma contribuição para a (re)construção da identidade cultural de estudantes adolescentes, especialmente naquelas em que a cultura afro-brasileira seja predominante, como na Bahia.

Dessa forma, esse estudo direcionou sua atenção para responder às seguintes perguntas, que ocuparam a centralidade do debate aqui pretendido: Os adolescentes da Escola identificam-se na obra de Pierre Verger? Quais os valores artísticos e étnico-culturais que podem ser identificados/percebidos pelos estudantes na obra de Verger?

Os problemas levantados por essas indagações nortearam a proposta pedagógica deste trabalho, que tomou como base os domínios dos seguintes saberes: processo de ensino/aprendizagem em artes, fotografia como arte, identidade cultural, e a obra de Pierre Verger. 


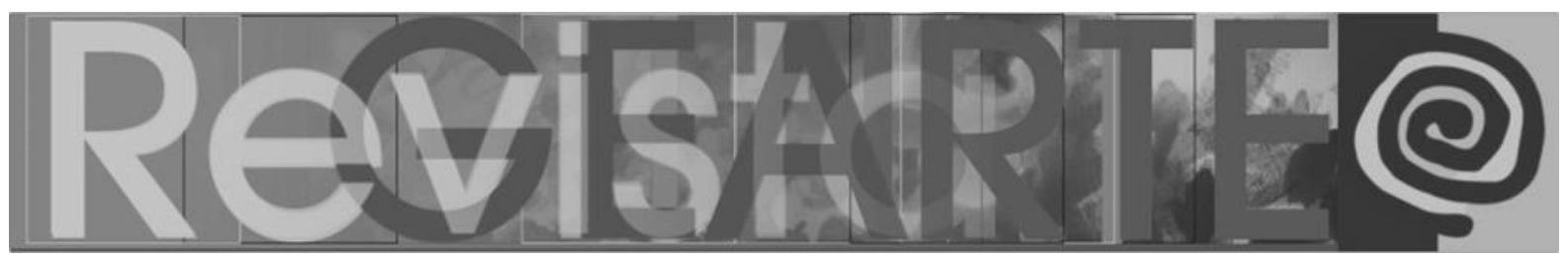

\section{O processo de ensino/aprendizagem em artes}

Para discutir ou repensar o processo de ensino-aprendizagem em artes não se pode prescindir dos trabalhos de Ana Mae Tavares Bastos Barbosa, principal referência em arte-educação no Brasil. Ao longo da sua trajetória, a autora de 35 livros e 129 artigos, publicados desde 1984, foi a pioneira em provocar e revolucionar os conceitos de ensino de artes nas escolas brasileiras. Barbosa reconhece que a ideia de que o processo de ensino-aprendizagem em artes tenha em sua base conceitual não só o fazer, mas o ver arte, "[...] tornou-se o cerne de todas as manifestações pós-modernas da arte/educação em todo o mundo" (BARBOSA, 2014 p. XXVI). E, que ao promover a leitura de imagens ou decifrar códigos hegemônicos, é possível estabelecer-se relações de diálogo e intercâmbio com outras propostas inovadoras e constituir-se em um projeto de alfabetização cultural, seguindo o ideário de Paulo Freire ${ }^{3}$. A sua sistematização em uma Proposta Triangular consiste em três abordagens para se construir conhecimentos em arte: Contextualização histórica (conhecer o contexto histórico do objeto artístico); Fazer artístico (fazer arte) e Apreciação artística (saber ler uma obra de arte).

De acordo com Arriaga (2014), além de introduzir a consideração das artes como oportunidade para o aprendizado, Barbosa abre as portas para uma concepção libertadora da educação artística. Mostra que a livre-expressão é insuficiente para uma adequada formação artística e que há necessidade da análise crítica por parte do espectador, formando consciências e não apenas especialistas em artes: "Uma educação libertária terá sucesso só quando os participantes no processo educacional forem capazes de identificar seu ego cultural, e se orgulharem dele" (ARRIAGA, 2014, p. XIX). A interpretação de Arriaga sobre o que Barbosa diz parece-nos ser extremamente lúcida quando reforça:

[...] o conhecimento e uso das artes podem cumprir um trabalho de resgate, de reestruturação social, de maneira a que a população permanentemente marginalizada das periferias conheça o jogo das 


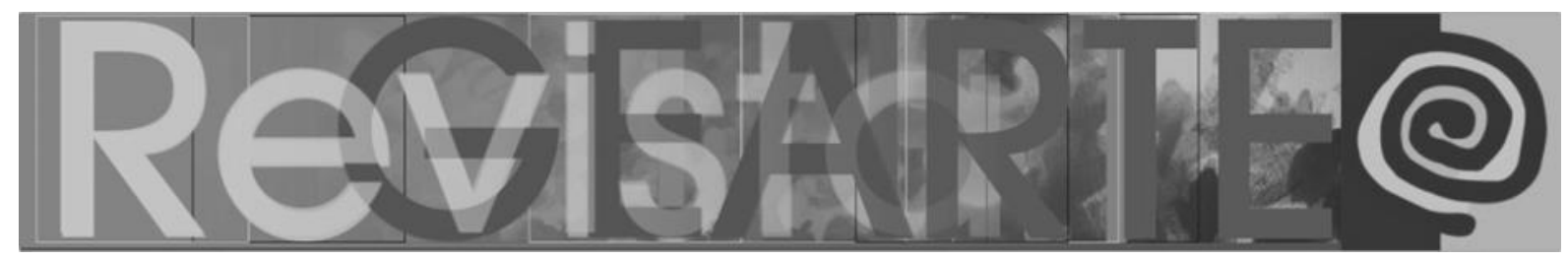

metáforas, dos códigos e os significados usuais entre aqueles que, durante séculos, determinaram o seu destino. (ARRIAGA, 2014, p. XXII).

O professor estadunidense Elliot W. Eisner (1933-2014) invoca a mensagem da arte como restauradora da concepção de escola, onde para além da evidência do fatual é o imaginativo que mais importa. Ele enfatiza aqui a mensagem do filósofo, pedagogo e, também, norte-americano John Dewey (1859-1952), referência no campo da educação moderna: "[...] enquanto a ciência declara significado, as artes expressam significado" (EISNER, 2008 p. 12).

Ao expressar significados, Ana Mae Barbosa traz um alerta recente em resposta aos desafios impostos pelo colonialismo cultural eurocêntrico e pela descolonialidade (BARBOSA, 2018). Ela rechaça a tendência em copiar modelos de ensino da Europa e dos Estados Unidos da América, sem que estes correspondam ao contexto social e à cultura do povo brasileiro, e enfatiza a necessidade de desenvolver, nos alunos, a consciência política, a análise da História, a desmistificação dos mitos colonizadores, o estudo de movimentos e heróis descolonizadores. Nesse processo de ensino/aprendizagem das artes, no contexto da Proposta Triangular, Araújo e Oliveira (2013) refletem sobre as mudanças nas práticas pedagógicas de leitura e análise de imagens, nas quais o papel mediador do professor torna-se essencial na construção do conhecimento. Principalmente em uma sociedade cada vez mais tecnológica e imagética.

\section{A fotografia como linguagem artística}

As artes visuais são as que privilegiam a visão como forma de expressão. Para além dos períodos históricos ou pré-históricos a representação de pessoas ou cenas do cotidiano eram expressas pelo pintor retratista, trabalho privilegiado $e$ encomendado pelos ricos e poderosos nas cortes e impérios da época medieval em diante. Com o advento da máquina fotográfica e seus recursos técnicos na virada para o século $X X$, as imagens fotográficas vieram substituir a pintura-retrato libertando-a da figuração (democratizando o retratismo) e permitindo que os 


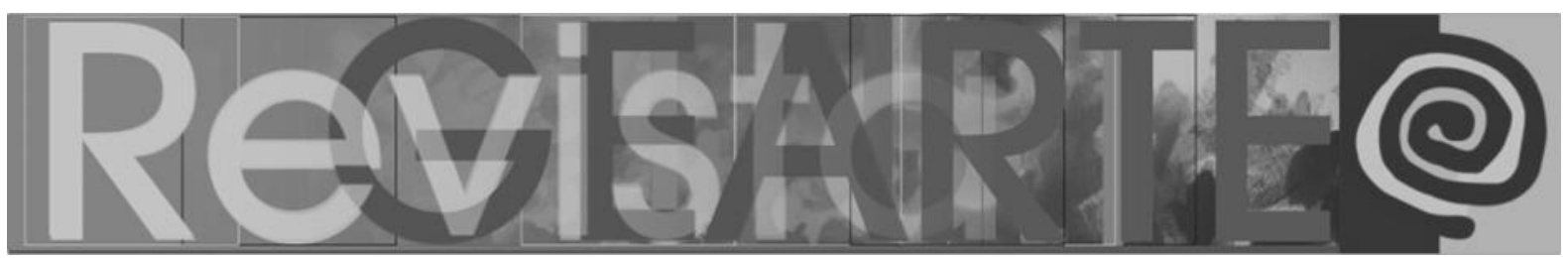

pintores dessem atenção às questões da forma e matéria e à sua possível abstração. Formou-se um sistema de representações e de significações, especificamente caracterizado por veicular uma informação visual, um registro da aparência visível do mundo: "O olhar se transforma em linguagem, ou seja, o visível em legível." (SOUTY, 2008, p.219)

Na visão da escritora americana Susan Sontag (1933-2004) a função da arte fotográfica como documento cultural, é atribuída à importância das fotografias que aconteceram em outra época, onde [...] "imagens que mobilizam a consciência estão sempre ligadas a determinadas situações históricas." (SONTAG, 2004, p.27). Mas, a fotografia evoluiu e ganhou um segundo papel, além da representação retratista/documental mera e simples, [...] "tornou-se um meio poderoso de expressão pessoal, do qual até os artistas de outras mídias se utilizam na construção de suas obras." (WOLFENSON, 2009, p.38)

Uma das máximas recorrentes do pensamento sobre fotografia é fornecida pelo fotógrafo brasileiro Bob Wolfenson:

[...] mais que um ofício, fotografar é uma maneira de se comunicar com o mundo, tanto de captar quanto de emitir; a partir da realidade explícita, observada e capturada, criar uma realidade própria, uma visão particular, singular, do real. (WOLFENSON, 2009, p. 34)

Wolfenson questiona o papel do artista no fotógrafo e postula que [...] "querer ser artista ou não querer, vai além de nossa vontade." (WOLFENSON, 2009 , p.35). Fotógrafos que fizeram trabalhos puramente documentais e jornalísticos tornaram-se ícones da arte fotográfica, como o francês CartierBresson, o húngaro naturalizado americano Robert Capa e o brasileiro Sebastião Salgado. No Brasil, os fotógrafos franceses Pierre Verger e Marcel Gautherot tornaram-se expoentes na arte fotográfica em um período conturbado pela Segunda Guerra Mundial. Ambos vieram direcionados pela obra de Jorge Amado publicada na França, ambos tiveram suas obras expostas e publicadas no mundo e ambos alcançaram enorme notoriedade. $\mathrm{Na}$ visão de Wolfenson, esses dois 


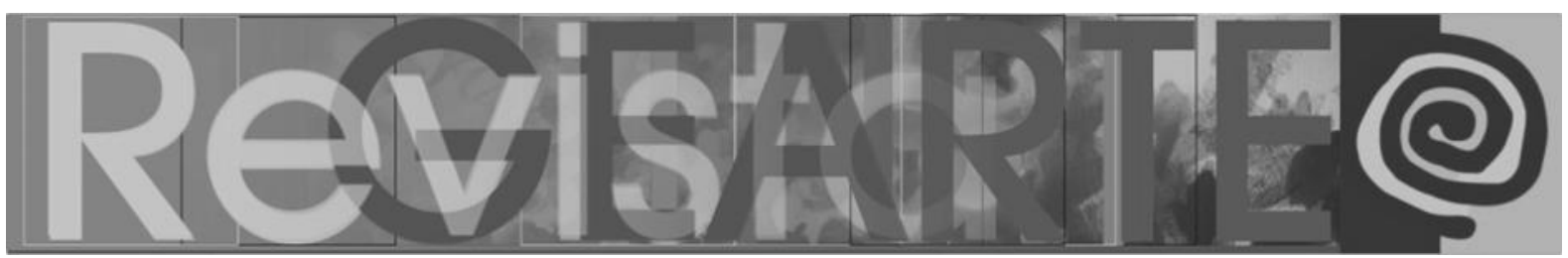

fotógrafos mantiveram um olhar europeu sobre a cultura e folclore brasileiro, mas de maneira distinta. Diferentemente de Gautherot, [...] "Verger adentrou-se totalmente na cultura afro-brasileira da Bahia, protagonizando a pessoa do negro, tornando-se uma figura importante e participante nos ritos religiosos do candomblé." (WOLFENSON, 2009, p.35, 36).

Atualmente, a fotografia é parte do nosso quotidiano, sendo um dos seus traços mais característicos o fato de estar presente em todos os estratos sociais. Os avanços tecnológicos das câmeras fotográficas permitiram a popularização das imagens fotográficas e maior agilidade na ação. Desde as câmeras de $35 \mathrm{~mm}$ até as câmeras digitais, e atualmente com a evolução dos celulares com câmera fotográfica, nunca se fotografou tanto e nunca houve tanta necessidade de imagens que se tornassem memoráveis. A Mobgrafia (fotografia com celular) é uma forma mais instantânea de captar imagens muito mais ágil na circulação de informação. Com os celulares pode-se captar uma imagem com qualidade, tratála com aplicativos e exportá-la para redes sociais em menos de dois minutos. Essa instantaneidade traz como consequência uma nova maneira de ler o mundo, permitindo o acesso a novos códigos culturais e ainda (re)configurá-los, uma vez que traz uma visão multicultural alcançada principalmente pela conexão das redes sociais (Facebook, Instagram, etc.).

\section{A identidade cultural}

As diferentes concepções da identidade cultural e social são extensamente abordadas pelo teórico-sociólogo jamaicano/britânico Stuart Hall (1932-2014), com base nos seus estudos sobre a diáspora negra caribenha ${ }^{4}$. Hall entende que ao reivindicar/reconhecer a identidade, há uma reconstrução através de uma diferença não dicotômica, já que o passado sofre constante transformação. As identidades refletem experiências históricas e códigos culturais em comum que dão um sentido de unicidade, as quais tiveram um papel predominante nas lutas pós-coloniais (HALL,1989, p.69). Em um senso comum, [...] "a identidade é 


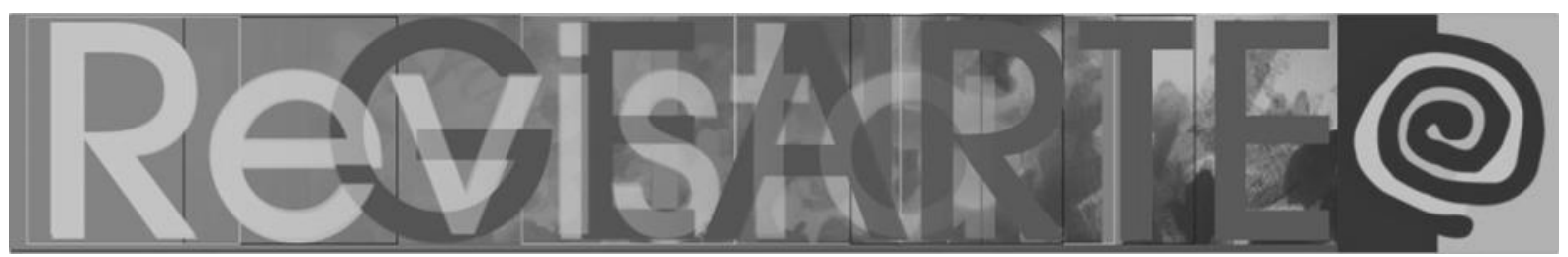

construída a partir do reconhecimento de alguma origem comum ou de características que são partilhadas com outros grupos ou pessoas, ou ainda a partir de um mesmo ideal." (HALL, 2014, p.106)

Na Bahia, a importação de escravos africanos começou em seguida ao estabelecimento dos primeiros engenhos de açúcar, próximo a 1550 e por quase 100 anos foi o trabalho escravo a base da economia da província. "Aqui vieram africanos que pertenciam às mais diferentes nações, as mais conhecidas devido às linguagens iorubas, ewes, jejes, fulas, tapas, aussás (malês), ardas e calabares." (TAVARES, 2001, p.55) Kabengele Munanga, especialista em antropologia da população afro-brasileira, afirma que os antepassados africanos brasileiros de hoje são oriundos de várias sociedades africanas, ou seja, de um pluralismo étnico-linguístico. Porém, ao serem submetidos ao trabalho escravizado não se mantiveram etnicamente separados, e sim submetidos juntos ao trabalho escravizado. Não havia outra forma de sobrevivência que não a de se aculturarem em uma única cultura, conservando as diferenças regionais. Essa cultura única, que Munanga chama de africanidade (grifo nosso) [...]"está na música, na dança, nas religiões de matrizes africanas e/ou nas artes visuais, as chamadas artes afrobrasileiras." (MUNANGA, 2018, p. 604-605). Por outro lado, a experiência da diáspora e as ações de resistência fizeram surgir um sentimento de pertença mais amplo que o vivenciado pelos africanos. O sentimento de pertença relatado por Munanga está relacionado à historicidade, às ações de liberdade, ao sentimento de desenraizamento (MUNANGA, 2007).

Mas, Munanga também chama a atenção para o fato do Brasil ser um país onde existem pessoas negras que introjetaram o ideal de branqueamento, que não se consideram como negras, de maneira a tornarem 0 processo de construção/resgate identitário um processo doloroso. Segundo ele, os conceitos de negro e de branco têm um fundamento etno-semântico, político e ideológico, mas não biológico. No contexto atual brasileiro essa questão conceitual é complexa, quando se colocam em foco políticas de ações afirmativas, como as 


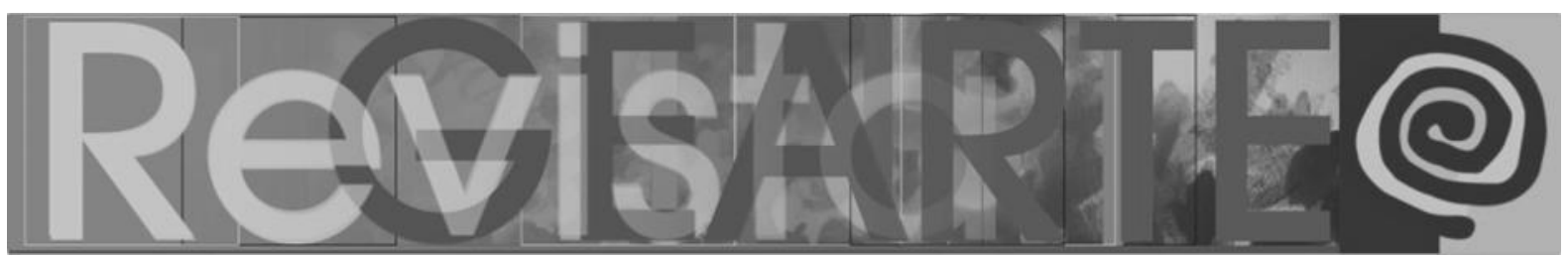

cotas $^{5}$. Além disso, Munanga contesta o conceito de afrodescendente, como forjado pelos próprios negros na busca da unidade com os mestiços. Ele lembra que, com os estudos da genética molecular, fica evidente que muitos brasileiros aparentemente brancos trazem marcadores genéticos africanos, ou seja, podem se dizer afrodescendentes (MUNANGA, 2004).

A globalização, por outro lado, trouxe as questões do multiculturalismo e das diferenças entre os povos as quais tiveram que ser incluídas nos temas centrais na teoria educacional crítica e nos projetos pedagógicos oficiais (haja vista os PCNs).

\begin{abstract}
A homogeneidade cultural promovida pelo mercado global pode levar ao distanciamento da identidade relativa à comunidade e à cultura local, mas também pode levar à uma resistência que fortalece e reafirma algumas identidades nacionais e locais, ou levar ao surgimento de novas posições de identidade (WOODWARD, 2014 p.21).
\end{abstract}

\title{
A obra de Pierre Verger
}

Pierre Edouard Leopold Verger (1902-1996), conhecido como Pierre Fatumbi Verger, fotógrafo e etnólogo autodidata franco-brasileiro, viveu em Salvador, Bahia, durante quase 60 anos. A sua chegada na Bahia, em 5 de agosto de 1946, é descrita poeticamente por ele mesmo no livro Retratos da Bahia: 1946 a 1952, quando refere a sua ansiedade em conhecer a Bahia de Jorge Amado relatada pelo amigo e sociólogo francês Roger Bastide (1898-1974). O momento da chegada na Bahia de Todos os Santos, em navio e à noite, mostrou logo para Verger uma cidade iluminada na encosta que margeia o porto. Assim, as suas primeiras impressões ficaram gravadas aí não só pelo cenário mágico da cidade amanhecendo, como pela alegria contagiante dos seus companheiros de viagem, conforme seu próprio relato no prólogo do livro supracitado:

[...] a alegria era tamanha a bordo que se mostrou inútil tentar dormir até o amanhecer. Foi então que assisti, pela primeira vez, a maravilhosa orquestra de garrafas vazias e pratos, batidos na cadência do samba de roda, e o som agradável que podem produzir as batidas ritmadas dos dedos sobre uma caixa de fósforos, acompanhando a letra de uma modinha sentimental ou irônica. Do convés do navio vimos nascer, na 


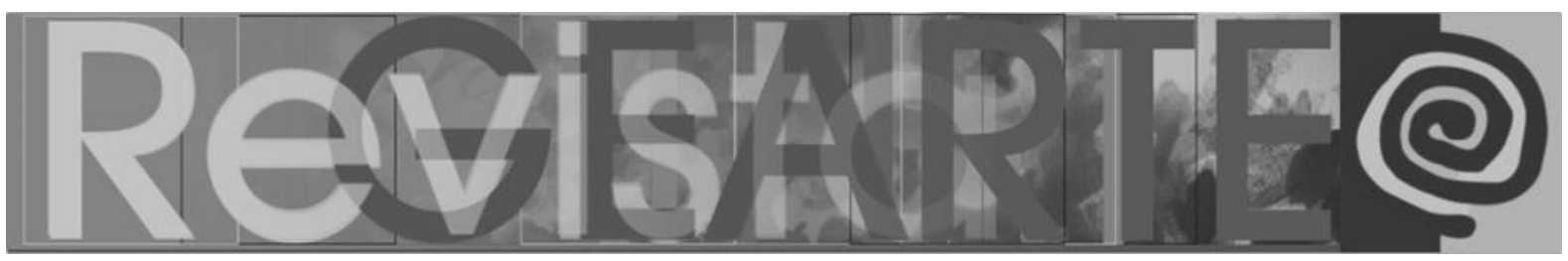

madrugada, os primeiros reflexos do sol, destacando-se deste fundo luminoso, as silhuetas das torres das igrejas da Cidade Alta. (VERGER, 1990, não paginado).

Importante salientar que Verger chega na Bahia em um período de efervescência cultural e artística, pós-guerra mundial e pós-ditadura no Brasil (Estado Novo), em um clima de reconstrução democrática e busca de saber. Não é coincidência que a Universidade Federal da Bahia (UFBA) tenha sido criada exatamente nesse ano. É o período do governo de Otávio Mangabeira (19471951), segundo o historiador Luis Henrique Tavares, o primeiro a realizar uma política de apoio e incentivo à cultura na Bahia (TAVARES, 2001). Destaca-se, nesse período, a figura de Anísio Teixeira ao criar o Departamento de Cultura na Secretaria de Educação e Saúde o qual se tornou o centro de apoio e inovação às artes plásticas, música, teatro, cinema e literatura baianas. Em paralelo às ações assertivas do governo na cultura, a situação econômica melhora "[...] com a alta do preço do cacau e a evidência de petróleo na Bahia." (TAVARES, 2001, p. 463). A recém criada Petrobrás ${ }^{6}$ anima e aquece a economia do país. A identidade nacional, o regionalismo, a descoberta do patrimônio cultural, erudito e popular, coincidiram na Bahia com o advento do modernismo. No seu livro Avant-garde na Bahia, o antropólogo Antonio Risério retrata a passagem de personagens estrangeiros que foram importantes na história cultural da Bahia (RISÉRIO, 1995). $\mathrm{O}$ autor descreve como conviveram na Bahia desse período, além de Pierre Verger, artistas estrangeiros como Carybé e a arquiteta Lina Bo Bardi. Ao interagirem com gente nativa, eles viram uma cultura popular viva, organizada, densa e inventiva, além de uma juventude inquieta, contestadora e criativa apoiada por uma instituição universitária (UFBA) com a criação de projetos culturais: "Neste sentido, podemos dizer que a Bahia reproduzia, em dimensão nacional, a situação do Brasil no mundo, culturalmente falando: um país economicamente periférico que apesar disso, era também, em termos culturais, um centro" (RISÉRIO, 1995, p. 135). 


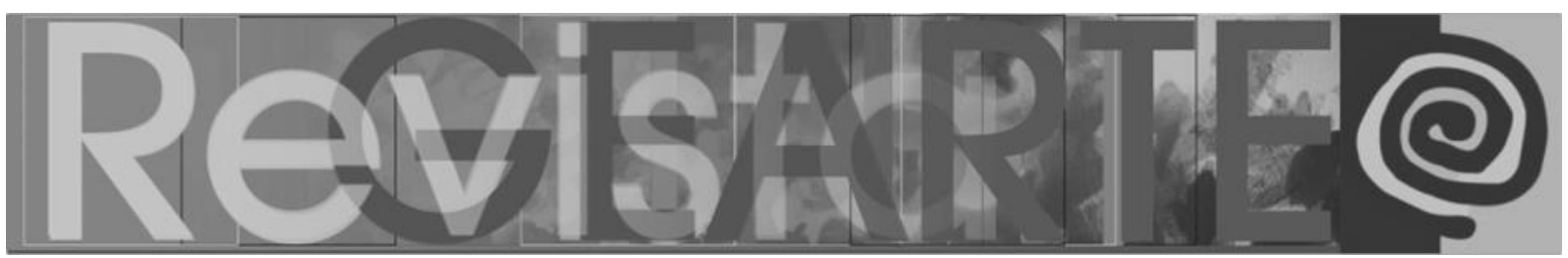

"O Cinema Novo e a Tropicália foram as duas grandes expressões estéticoculturais da onda geracional baiana que fez a sua estreia na década de 60" (RISÉRIO, 1995, p. 139). Mas, se essa década foi marcada por uma grande atividade artística, por outro lado, foi também marcada por um regime militar calcado no poder transgressor dos direitos de cidadania e agente repressor das manifestações culturais. Surgia uma nova geração, despontando em exposições, museus e galerias. A museóloga e ex-diretora do Museu de Arte da Bahia, Sylvia Athayde (1940-2015), comenta esse período em um depoimento no portal de notícias Leiamais.ba (www.leiamais.ba), trazendo um cenário realístico do que se vivenciou naquele momento: "a censura reprimindo tantas formas de expressão e o espírito inquieto dos artistas em busca da contemporaneidade, motivou uma efervescência cultural que marcaria a história" (ATHAYDE, 2009).

Verger viveu, portanto, esses primeiros 20 anos de Bahia acompanhando toda a dinâmica e esse despontar da arte moderna e do cotidiano da sociedade em Salvador, em um contexto político-social conturbado do país. No entanto, segundo o antropólogo francês Jerôme Souty (2008), Verger não pretendeu jamais integrar um movimento artístico ou uma vanguarda qualquer que fosse, porque sua prática sempre foi isolada e não se inscrevia em uma trajetória experimental ou em um projeto artístico premeditado. Apesar desse perfil de olhar livre (grifo nosso), Souty considera a primeira estadia de Verger em Salvador, um marco e uma grande ruptura em sua vida e carreira, porque é quando ele descobre as culturas afro-brasileiras.

Fui seduzido na Bahia pela presença de numerosos descendentes de africanos e por sua influência sobre a vida cotidiana deste lugar. Minha atenção era tão monopolizada por eles e pelos mulatos que durante muito tempo nem sonhava em apontar a minha Rolleiflex em direção de pessoas mais anêmicas. (VERGER, apud Risério, 1995, p. 88).

Será o início de uma vocação afro-americanista, depois africanista, para a qual irá se dedicar o resto de sua vida. É seguindo essa vocação que Verger se concentra progressivamente em um objeto de estudos, aprofundando temas da 


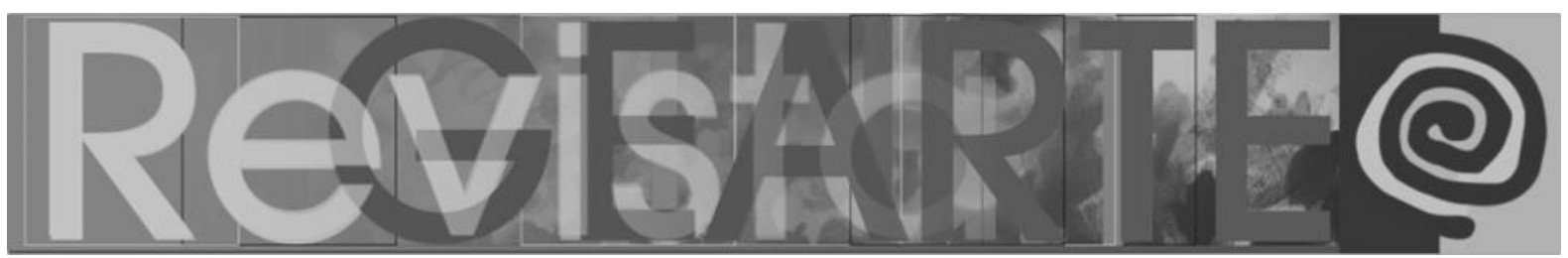

cultura africana e afro-brasileira e gradativamente deixa certa espontaneidade anterior. "A fotografia vem a ser para ele um modo de desenvolver e valorizar seu trabalho etnológico" (SOUTY, 2008 p. 219).

Segundo Martini (1999), Verger construiu, através de suas fotografias, uma imagem positiva do negro direcionada para a população afro-brasileira, trazendo uma linguagem de interseção entre a fotografia e a etnologia. Exemplo disso é o livro Orixás, Deuses Iorubás na África e no Novo Mundo, em sua nova edição (2018), com fotos inéditas e um prefácio assinado por Mãe Stella de Oxóssi, lalorixá do Axé Opô Afonjá. O livro é fruto das constantes viagens de Pierre Verger à África entre os anos de 1948 e 1965 e apresenta textos e ilustrações que comentam e mostram aspectos do culto aos orixás, deuses dos iorubás, em seus lugares de origem, na África (Nigéria, ex-Daomé e Togo) e no Novo Mundo (Brasil e Antilhas). "É importante ressaltar que praticamente toda a sua obra escrita (excluindo as publicações de álbuns e livros fotográficos) refere-se ao contexto da cultura iorubá, tanto na Nigéria e Benin (África) quanto na diáspora nas Américas" (LUHNING, 1998, p. 325).

Em resenha publicada em 2014, Isabela Gaglianone comenta o único livro autobiográfico de Pierre Verger_50 anos de fotografia 1932-1982 (1988) reeditado pela Fundação Pierre Verger em 2011. A autora interpreta o trabalho fotográfico historiográfico de Verger mostrando que é desenvolvido através de uma linguagem própria e com um espírito inconfundível, e não limitado a um simples documentário:

\footnotetext{
Os temas humanos em suas fotografias perduram um olhar inteligente, sintético e metafórico. São imagens líricas, que encerram em si um tempo articulador do entendimento humano com a natureza das coisas, o tempo do olhar, do andar, pedalar, navegar: um tempo que se dá tempo de ser, a essência do ser cultural. (GAGLIANONE, 2014, s/p.).
}

Considera-se aqui que o olhar etnográfico de Verger, sua paixão pelo ser humano e pela cultura africana, transformou sua obra fotográfica em uma representação ímpar da identidade cultural afro-brasileira. 


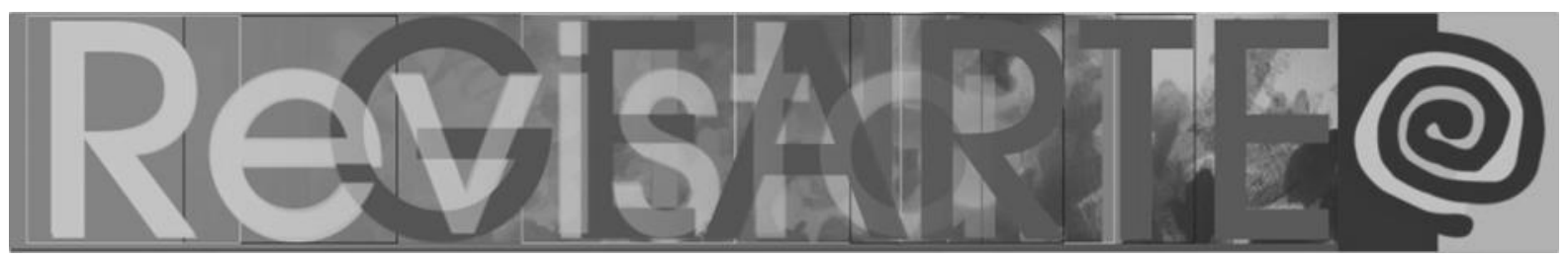

\section{Procedimentos metodológicos}

A ação dialógica levou em consideração primordialmente o entendimento de Freire (1996) de que é através da cultura que ocorre o processo de resistência e o fortalecimento das identidades. Para o educador, o caminho é sempre o diálogo, o que o leva a defender que as ações culturais devem ser problematizadoras das condições dos sujeitos nelas implicados. Esse diálogo não é neutro, cabe ao educador, no papel de mediador, estimular a emancipação e empoderamento do educando. Essa é a primeira linha metodológica aqui seguida. A segunda diz respeito ao procedimento metodológico abordado por Araújo e Oliveira (2013), tendo como base a Proposta Triangular. Assim, nessa proposta metodológica há uma distinção entre 3 eixos norteadores: contextualização, leitura da obra de arte e o fazer artístico.

Para a Contextualização, foram utilizadas aulas expositivas sobre a história da fotografia e sobre a vida de Pierre Verger. Procurou-se dar um enfoque no período histórico desses acontecimentos e identificar os tipos e elementos de identidade cultural (lugar, gênero, nacionalidade, idioma, crença religiosa e etnia).

Para a Leitura/apreciação da obra de Verger, foram utilizados livros sobre Pierre Verger, aulas expositivas com a projeção de imagens obtidas por Verger, com o recurso Power Point. Para iniciar o processo de sensibilização dos alunos, foi realizada uma atividade de leitura e releitura das obras de Candido Portinari (1903-1962), contemporâneo de Verger, a partir de um olhar sobre a identidade cultural do povo brasileiro, em que foram trabalhados os mesmos elementos que seriam nas imagens de Verger.

Para o Fazer artístico, foram utilizadas 30 imagens selecionadas do acervo da Fundação Pierre Verger. Essas foram enviadas para os alunos via Whatsapp e por e-mail, cada aluno escolheu três das imagens, a partir das quais fotografaram cenas do seu cotidiano de acordo com a releitura que fizeram delas. Ao escolherem 


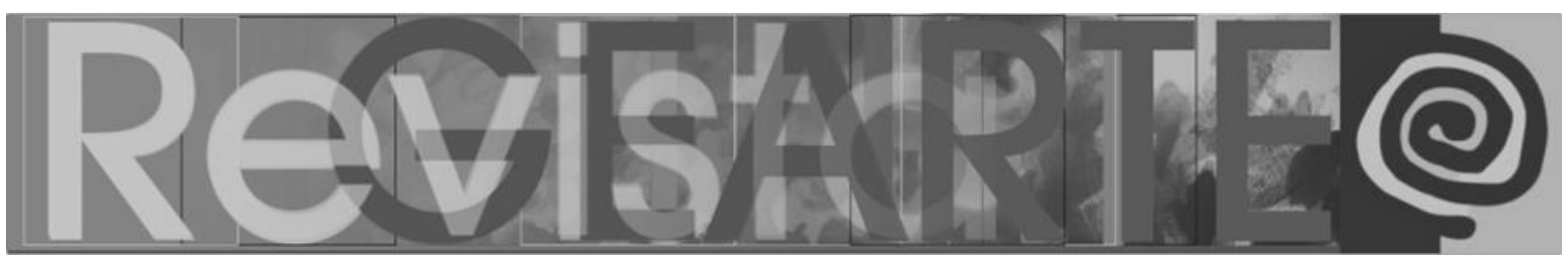

as imagens responderam ao questionário, que foi enviado à professora, junto às fotos tiradas.

"A leitura de imagens é um processo de aquisição de conhecimentos por meio da percepção, interpretação e decifração de códigos emitidos pela imagem" (BALISCEI e TERUYA, 2013, p. 18069). No processo de ensino/aprendizagem em artes, passa a ser uma ferramenta didática que professores se utilizam para alcançar o objetivo de aguçar ou estimular a compreensão estética dos alunos em relação a uma obra de arte. Ao descreverem o que estão "lendo" estarão interpretando, mediados pelo professor, em uma atividade de reflexão teórica sobre as imagens. O papel do professor como mediador da aprendizagem será o de estimular o adolescente (ou criança) a desenvolver a capacidade estética, explorando o universo infinito das imagens. No entanto, promover a apreciação da imagem é compartilhar as experiências culturais que os alunos já trazem de suas vivências cotidianas. Dessa forma, aproveitar esses conhecimentos é de fundamental importância para a construção da linguagem visual. Enquanto a leitura interpreta e decifra os códigos, a releitura de uma obra artística transcende o fazer artístico quando entendida no seu sentido maior, qual seja, o de expressar novos significados.

$\mathrm{Na}$ prática, o que chamamos de releitura consiste em criar uma produção inspirada nos elementos, signos, símbolos e códigos contidos em uma obra de arte, porém, com um novo olhar, incluindo elementos de acordo com a intenção de quem cria. "Como uma criação a partir de outra, a releitura pode ser entendida como uma atualização do olhar que constantemente se transforma e que se sobrepõe a cada nova leitura, pois ao fazê-la, amplia-se o olhar, acrescenta-se novos significados" (BALISCEI e TERUYA, 2013, p. 18073). É importante salientar que a imaginação, a criatividade e as experiências visuais que os alunos possuem, é que irão dar sentido a criação, para que a releitura não seja entendida como cópia. 


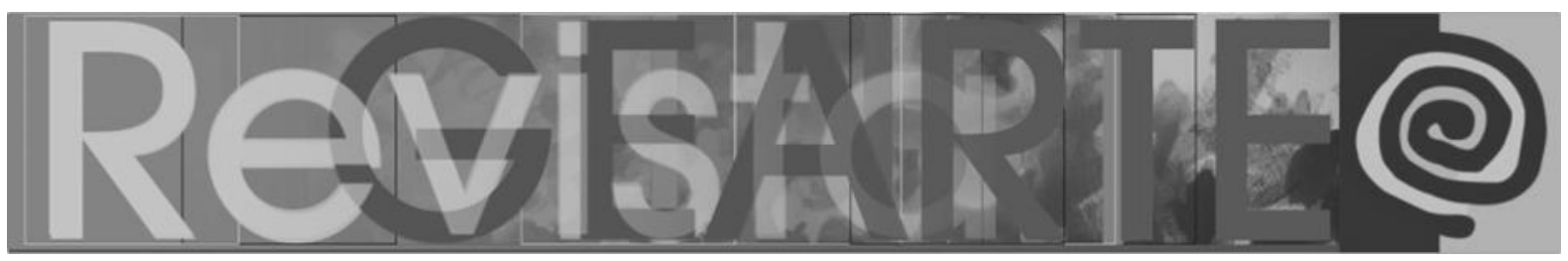

Quando um aluno observa obras de arte e é estimulado (e não obrigado) a escolher uma delas como suporte de seu trabalho, a sua expressão individual se realiza da mesma maneira que se organiza quando o suporte estimulador é a paisagem que ele vê ou a cadeira de seu quarto. A obra observada é um suporte interpretativo (grifo nosso), não um modelo. (BARBOSA, 2014, p. 118).

\section{Desenvolvimento da proposta pedagógica}

O planejamento das aulas foi realizado de acordo com o método adotado, dentro das limitações impostas pela infraestrutura da escola e do calendário escolar, tendo em vista sempre o período final, devido à característica específica do mês de novembro (consciência negra). Considerando o eixo temático da disciplina, Conhecimento e Expressão em Artes Visuais, decidiu-se trabalhar três temas específicos: 1) Percepção Visual e Sensibilidade Estética (apreciação e análise de imagens e objetos artísticos); 2) Relações entre as artes visuais e seu contexto na contemporaneidade; 3) Expressão e elementos formais nas obras das artes visuais. Dentro dessa temática e considerando os objetivos desse trabalho ao introduzir a linguagem fotográfica, foi estabelecida a meta de desenvolver, durante as aulas, os conhecimentos pretendidos por meio de atividades práticas de leitura de imagens, contextualizadas historicamente, além de capacidade criativa por meio de produção de imagens na linguagem fotográfica.

Para o primeiro tema, foi realizado um exercício sobre leitura e releitura de imagens, com o propósito de sensibilizar os alunos para o trabalho nos encontros seguintes com as fotos de Verger. Para direcionar essa abordagem foram selecionadas obras de Candido Portinari, propositalmente a partir de um olhar sobre a identidade cultural do povo brasileiro: que tivessem como foco principal homens brasileiros dentro do contexto histórico-social do país: O mestiço (1934), O lavrador de Café (1934), Café (1935). Constou da projeção das imagens, pesquisa sobre o artista, contexto histórico do Brasil e do mundo, além da produção de releituras em desenhos, significadas através de alguns elementos inseridos em suas próprias vivências. Os próximos seis encontros foram desenvolvidos dentro dos objetivos do projeto Verger, em um processo sequencial. Inicialmente, foi 


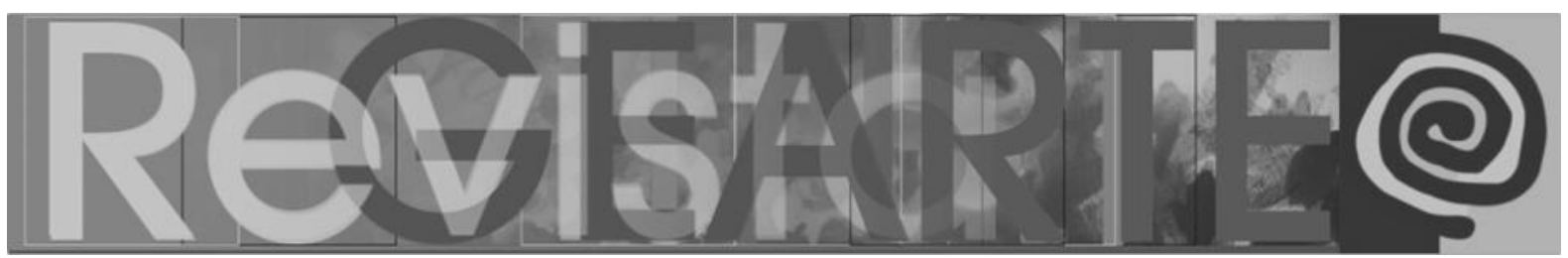

introduzido o contexto da imagem fotográfica como linguagem artística, os primeiros fotógrafos brasileiros, ressaltando a importância da linguagem da fotografia no registro de imagens do Brasil. Nas imagens projetadas em vídeos, foram mostrados seus elementos básicos como luminosidade, enquadramento, movimento, direcionamento do olhar e angulação de planos, além dos diversos níveis de percepção/apreciação (tipos de sentimentos aflorados) nas obras e dos elementos estéticos na fotografia (enquadramento, forma, cor, luz, volume, espaço, superfície, movimento). Na etapa seguinte, dentro da abordagem do segundo tema, foi introduzida a obra de Verger e fornecidas as primeiras orientações sobre o que e como os alunos teriam que apresentar na finalização do projeto. Foi projetado um vídeo curto sobre sua chegada na $\mathrm{Bahia}^{7}$ e comentadas as imagens do livro Retratos da Bahia (VERGER, 1990). Nas imagens, foi possível identificar e comentar as diferenças e semelhanças dos locais atuais, do vestuário, do transporte, da construção das casas e das ruas. No terceiro tema, foram enviadas 30 imagens pré-selecionadas do acervo de fotos da Fundação Pierre Verger, nas quais os alunos selecionaram três para fazerem a sua releitura e construção do conhecimento artístico sobre elas.

Os alunos enviaram as fotos das releituras, tiradas por celulares, via tecnologias digitais (Whatsapp e correio eletrônico), junto ao questionário respondido. Selecionamos aqui algumas releituras, com as observações correspondentes dos alunos (Figuras 1 a 3 ). A exposição de final de ano foi realizada com as fotos recebidas, que foram impressas em papel $A 4$, organizadas para serem expostas em dupla: cada foto de Verger junto à foto de releitura do aluno. É importante ressaltar que, na exposição, houve participação dos familiares, da comunidade e mesmo de professores e funcionários da escola, muitos trazidos pelos próprios alunos em momentos de muito entusiasmo.

Na Figura 1, o aluno AMLF observou que a foto foi tirada na África e que as pessoas estavam raspando o cabelo para algum tipo de ritual. O que mais the chamou atenção foi o rosto, a roupa e a lâmina, e ele distinguiu que a imagem representava 


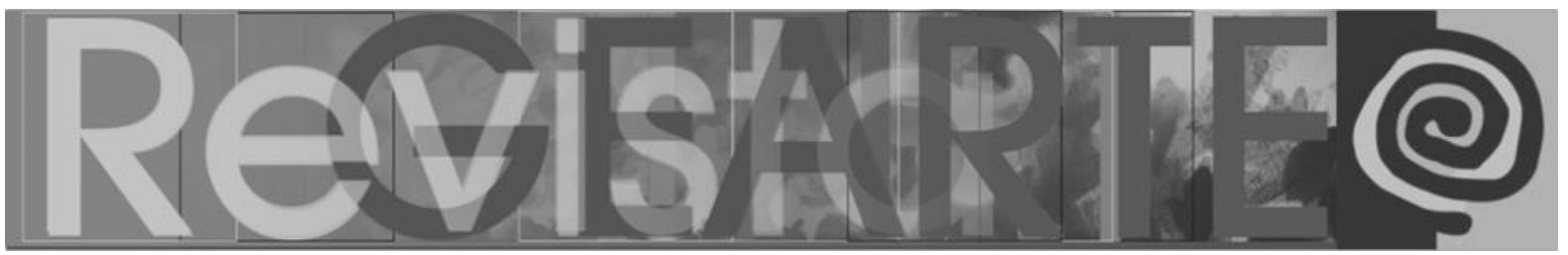

um ritual que não aconteceria agora, refletindo a releitura feita por ele. Identificou que Verger estava olhando para o enquadramento da foto e o movimento da imagem e destacou na imagem o enquadramento, a luminosidade e o movimento.

Figura 1 - Releitura do aluno AMLF relacionada à imagem de Pierre Verger
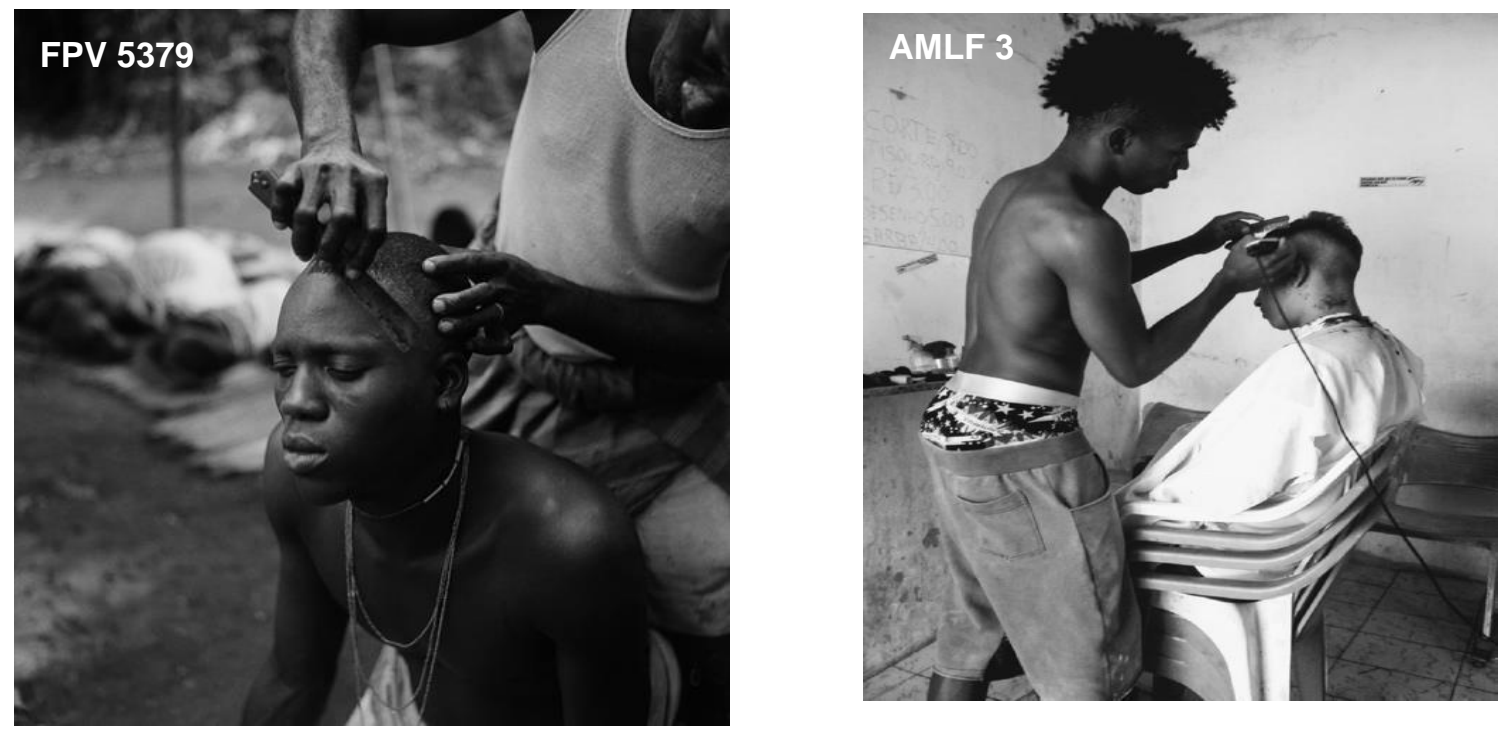

Fonte: FPV 5379 = Briki, Ifanhin, Bénin,1958. Foto Pierre Verger @ Fundação Pierre Verger; AMLF 3= arquivo das autoras.

Na Figura 2, a aluna ISS observou que a foto mostrava crianças em uma rua, reunidas, sentadas. Destacou as semelhantes nas roupas, as expressões faciais e observou que, mesmo atualmente, em sua região, é possível observar-se uma cena como essa, apesar da disponibilidade de novas tecnologias para brincar. Interpretou que o foco de Verger era exatamente a reunião, chamando a atenção para o enquadramento de todas as crianças.

Na Figura 3, a aluna ISB observou e identificou que o local da foto era Bahia, em um momento em que as mulheres estavam aproveitando o sol, abraçando-se. Chamou a sua atenção a expressão do rosto das mulheres onde na releitura foi mantida a forma contemplativa, além dos adereços e figurinos semelhantes facilmente encontrados na comunidade. Pela semelhança do que já tinha visto na 


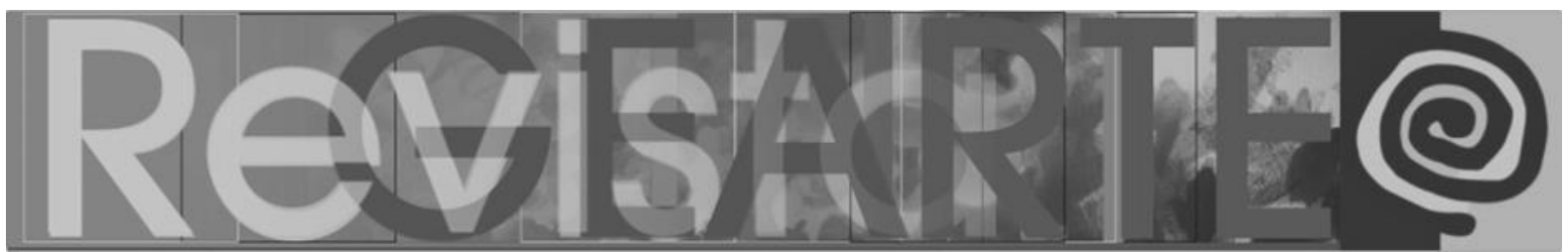

sua região, identificou as mulheres como baianas e praticantes do candomblé.

Destacou também na foto de Verger, a luminosidade e o enquadramento.

Figura 2 - Releitura da aluna ISS relacionada à imagem de Pierre Verger.
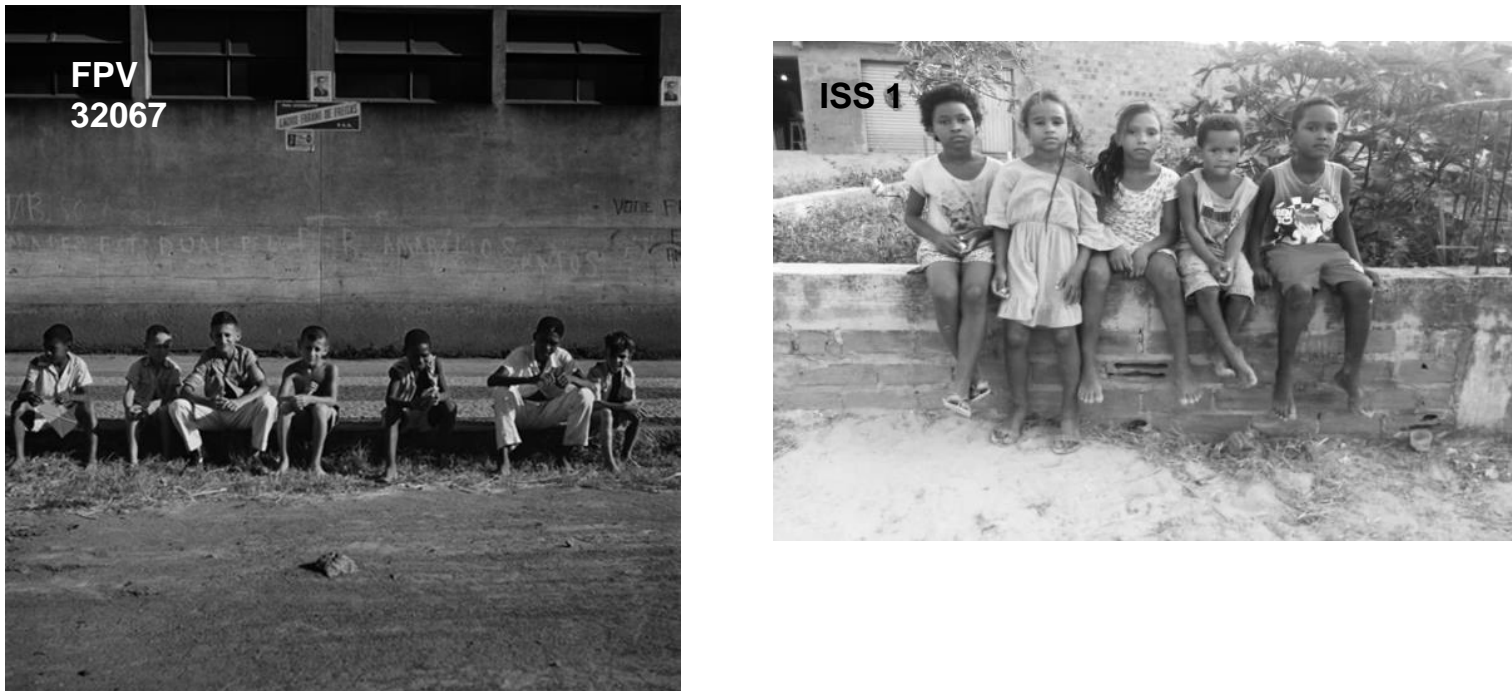

Fonte: FPV 32067= Cenas de rua, Salvador, Brasil, Anos 50 - Foto Pierre Verger @ Fundação Pierre Verger; ISS 1= arquivo das autoras.

Figura 3 - Releitura da aluna ISB relacionada à imagem de Pierre Verger
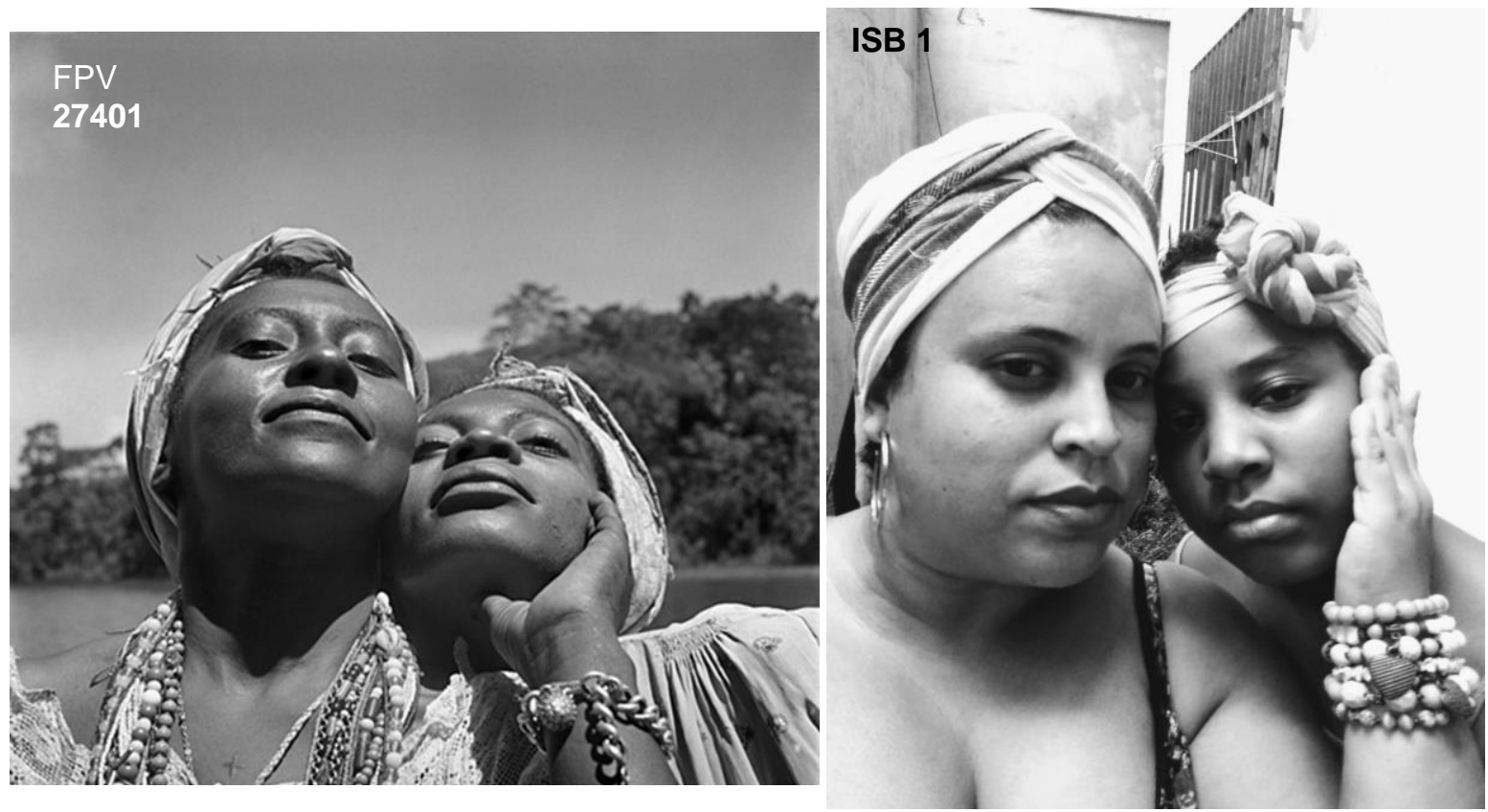

Fonte: Fonte: FPV 27401= Filhas de Santo, Candomblé Joãozinho da Gomea, Salvador, Brasil,1946 - Foto Pierre Verger (c) Fundação Pierre Verger; ISB 1= arquivo das autoras. 


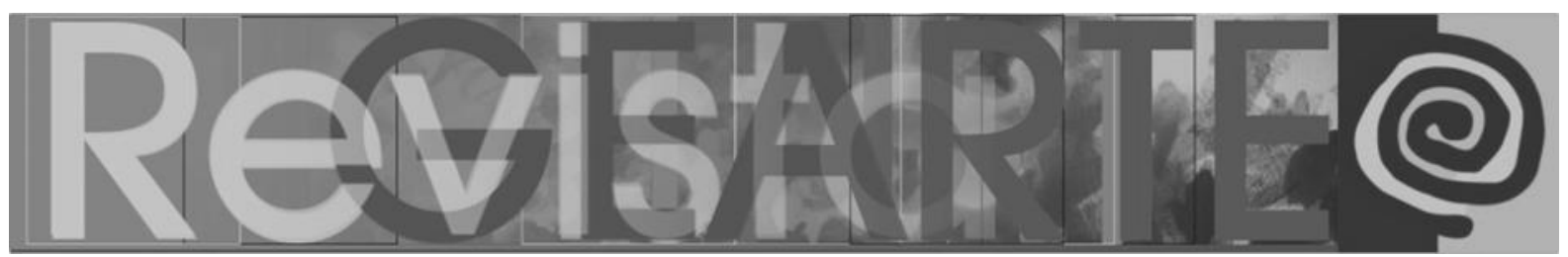

As releituras trouxeram percepções individuais, em alguns casos bem semelhantes umas das outras. Alguns alunos conseguiram destacar os elementos técnicos da fotografia, evidenciados nos olhares das pessoas retratadas por Verger, em algumas situações comparáveis a seus cotidianos e seus corpos, inseridos na cultura afrodescendente. Da mesma maneira, a preocupação em identificar os locais retratados na obra de Verger, relembrando o vídeo exibido na aula, e trazendo situações semelhantes nas releituras. Como a seleção das fotos de Verger foi realizada propositadamente refletindo corpos em seu cotidiano, a maioria das releituras apresentou pessoas da família ou da comunidade inseridos na região onde moram os alunos, no bairro de Vida Nova. Muitas delas identificaram claramente rituais religiosos do candomblé, identificadas por atividades comuns em sua rotina, como o fazer de um corte de cabelo, uma dança ou uma luta (capoeira) direcionados a um propósito contemporâneo cultural.

Algumas releituras indicaram ausência de preocupação na espontaneidade característica das imagens de Verger. Em outras, percebe-se um olhar sensibilizado pelas obras, demonstrando uma integração com a realidade cotidiana. Outras refletem uma cena montada e, ainda, outras fogem completamente dos corpos contidos nas imagens por eles mesmos selecionadas, o que indica não ter havido um olhar crítico e, nesse caso a obra observada de Verger passou a ser um modelo e não um suporte interpretativo, como refere Barbosa (BARBOSA, 2014, p.118). Apesar disso, muitas das construções de cenas reformularam as fotografias de Verger, usando adereços, vestuário e até mesmo a mesma posição de corpos em cenários que remetem às fotografias de 1940 como ruas, feiras e lugares. Todos produziram, como Verger, uma relação de equivalência na contextualização dos cenários, dos gestos ou das atitudes expressivas do corpo. A criatividade foi revelada na composição de ângulos, luzes, sombras e enquadramentos, tentando reproduzir o olhar do fotógrafo em suas obras. Lembraram-se, inclusive, de utilizar recursos como o contraluz e o contre plongée (low-angle shot) para destacar as formas dos corpos, definindo suas silhuetas e evidenciando o tipo de personagem fotografado. 


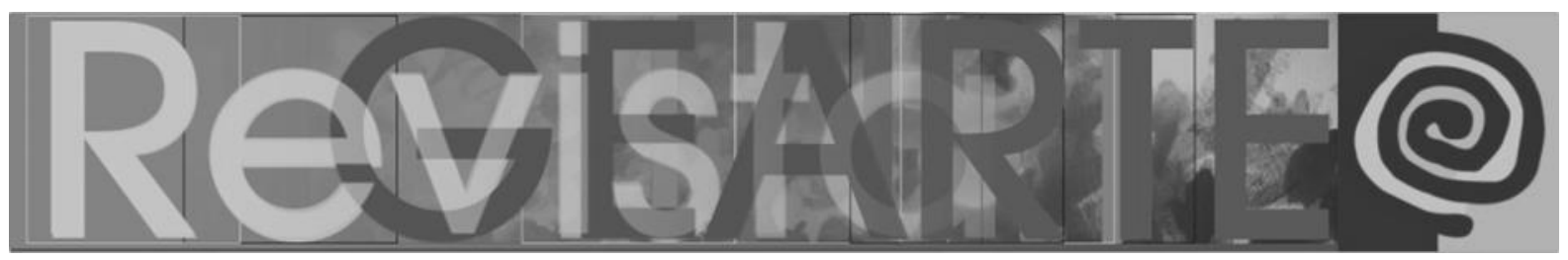

\section{Considerações finais}

Durante o transcorrer do projeto, em avaliação processual, foi possível observar os momentos estimuladores pelos olhares de atenção à algumas imagens e consequente verbalização ao comparar suas vivências com o contexto social da época de Verger. Diante dessa observação, é possível se fazer uma reflexão sobre o potencial criador e sobre a sensibilização do olhar e das percepções provenientes do cotidiano coletivo inserido na diversidade de suas linguagens aculturadas. Nesse processo de criatividade inserido em um contexto comunitário, a artista plástica Fayga Perla Ostrower (1920-2001) diz que é possível perceber a influência da cultura na visão de vida de cada um, já que a cultura "[...] orienta o ser sensível ao mesmo tempo que orienta o ser consciente.[...] Com isso a sensibilidade do indivíduo é aculturada e por sua vez orienta o fazer e o imaginar individual" (OSTROWER, 2014, p. 17.).

De uma maneira geral, a identificação com a obra de Verger pode ser percebida em grande parte pela aproximação das pessoas retratadas nas releituras com as retratadas nas fotos de Verger, não somente no protagonismo de amigos e familiares da comunidade de Vida Nova, como nos próprios alunos retratando-se em selfies. Os valores artísticos e étnico-culturais puderam ser identificados/percebidos nos corpos retratados em sua luminosidade, os olhares fortes, sorrisos marcantes, o vestuário e os movimentos cadenciados proveniente de uma cultura magnificamente representada nas obras de Verger. Pelas imagens registradas, fica visível a diversidade de elementos captados pelo olhar sensibilizado e voltado para o empoderamento de seus valores étnicos-culturais, mesmo não sendo intencional. É nesse aspecto do olhar sensibilizado que o ato de dar voz ao sujeito é possibilitado, ou seja, potencializa a autenticidade da autorrepresentação no seu registro fotográfico.

Percebe-se, claramente, a preocupação com o sentimento de pertença observado por Munanga (2007), através das roupas e adereços, posturas, 


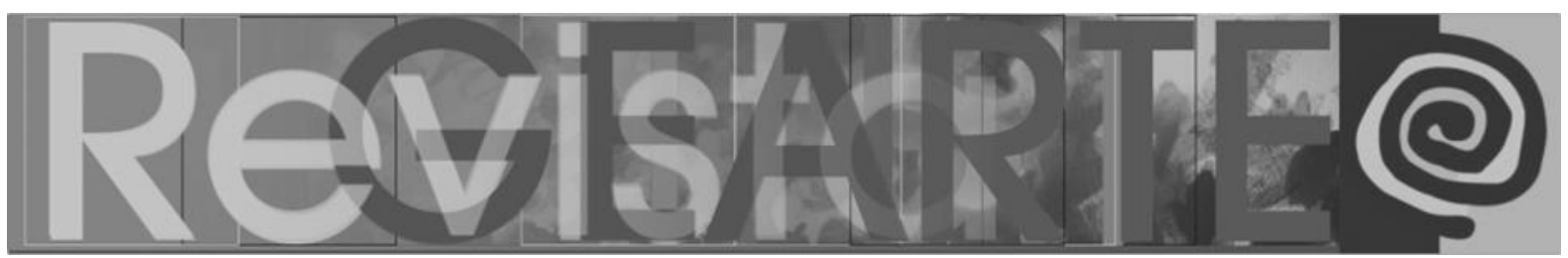

penteados, sorrisos e olhares que remetem a linguagens direcionadas ao empoderamento da cultura afrodescendente. Entende-se, aqui, que ao estabelecer o diálogo do aluno com as obras de arte, atuando como mediador nesse processo de ensino/aprendizagem, o professor pode estimular e trazer, para dentro da sala de aula, uma ressignificação diante de sua realidade sociocultural.

Para além desse olhar sensibilizado pela obra fotográfica de Pierre Verger, as produções realizadas pelos alunos, em seus celulares, convergem para um momento de inovação cultural, dessa vez, influenciados pela globalização e o multiculturalismo mundial disseminados e desenvolvidos pelas tecnologias digitais. Os alunos conseguiram interpretar as imagens, integrar-se em debates perceptivos da linguagem fotográfica e realizar a reflexão e comunicação necessárias ao processo de reconhecimento e valorização sociopolítico e histórico do seu espaço de convívio.

A escolha da obra artística fotográfica de Pierre Verger, como proposto neste trabalho, mostrou-se extremamente adequada à população estudantil de escolas públicas da Região Metropolitana de Salvador. Essa interface entre a fotografia e a etnologia, aliada ao perfil despretensioso do fotógrafo/artista, fazem emergir um diálogo enriquecedor na interpretação e decifração dos códigos emitidos pelas imagens. Para o professor, enquanto mediador do processo, emerge, também, um diálogo afetivo, que é consequência do impacto identitário e da sensibilização promovidas pelas obras de Verger e pelas releituras em seus elementos homólogos. Nesse contexto, a reflexão da prática educativa, que é feita aqui, converge para a importância da escuta e das relações interpessoais, o que exige do professor uma reflexão crítica permanente sobre essa prática. É como diz Paulo Freire: "[...] o trabalho do professor é o trabalho do professor com os alunos e não do professor consigo mesmo" (FREIRE, 1996, p. 33).

Consideramos que esse projeto foi exitoso na medida em que houve essa troca das práticas educativas e das reflexões críticas, respeitadas a identidade e 


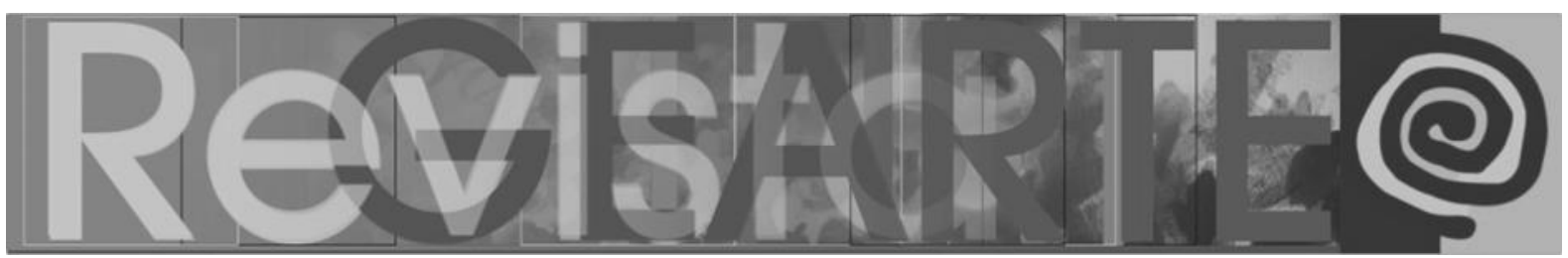

autonomia do "fazer". Importante salientar que, ao ter acesso às imagens de Verger e produzir as releituras, os alunos demonstraram não só uma preocupação estética da fotografia, mas também expuseram o seu sentimento de pertença. Entende-se que essa experiência fez com que eles se reconhecessem como extensão transformada de uma cultura ancestral. O foco para a africanidade, especificamente no Nordeste do Brasil, e, mais ainda, na Bahia, mostra não só o ser humano, mas o que o distingue etnicamente em suas singularidades culturais. $E$, nesse aspecto, isso transforma-se em um elemento estimulador das reconfigurações dos códigos culturais e da redefinição de leitura de mundo.

\section{Notas}

1 Não há consenso quanto ao uso do conceito decolonial/descolonial. Ambas as formas se referem à dissolução das estruturas de dominação e exploração configuradas pela colonialidade e ao desmantelamento de seus principais dispositivos. Aníbal Quijano, entre outros, prefere referir-se à descolonialidad, enquanto a maior parte dos autores utiliza a ideia de decolonialidad (Quintero et al, 2019).

2 Ver Brasil (2003).

3 A pedagogia formulada por Paulo Freire (1987), aceita a sugestão da antropologia: impõe-se pensar e viver a educação como prática da liberdade.

4 O termo diáspora é entendido como o deslocamento, normalmente forçado ou incentivado, de grandes massas populacionais originárias de uma zona determinada para várias áreas de acolhimento distintas.

5 Ou cotas raciais, termo oficial utilizado pelo governo brasileiro. São reservas de vagas em instituições públicas ou privadas para grupos específicos classificados por etnias, na maioria das vezes, negros e indígenas.

6 Petróleo Brasileiro S.A., criada em 1953, empresa estatal de economia mista, com sede no Rio

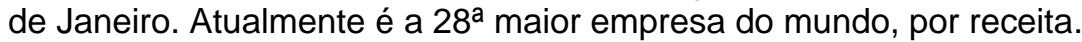

7 "Pierre Verger, chegar à Bahia", dirigido pelo cineasta argentino Carlos Pronzato (Pronzato, 2006).

\section{Referências}

ARAÚJO, Gustavo Cunha; OLIVEIRA, Ana Arlinda. Sobre Métodos de Leitura de Imagem no Ensino da Arte Contemporânea. Imagens da Educação, n.3(2):70-76, 2013. Disponível em: https://www.researchgate.net/publication/270084926. Acesso em: 14.07.2020. doi: 10.4025/imagenseduc.v3i2.20238.

ARRIAGA, Imanol Aguirre. Ana Mae Barbosa ou como navegar entre a fidelidade a um ideário e a "incessante busca de mudança". In: BARBOSA, Ana Mae Tavares Bastos. A imagem no ensino de arte: anos oitenta e novos tempos. 9a Edição. São Paulo: Editora Perspectiva Ltda, 2014 p. XI a XXIV. 


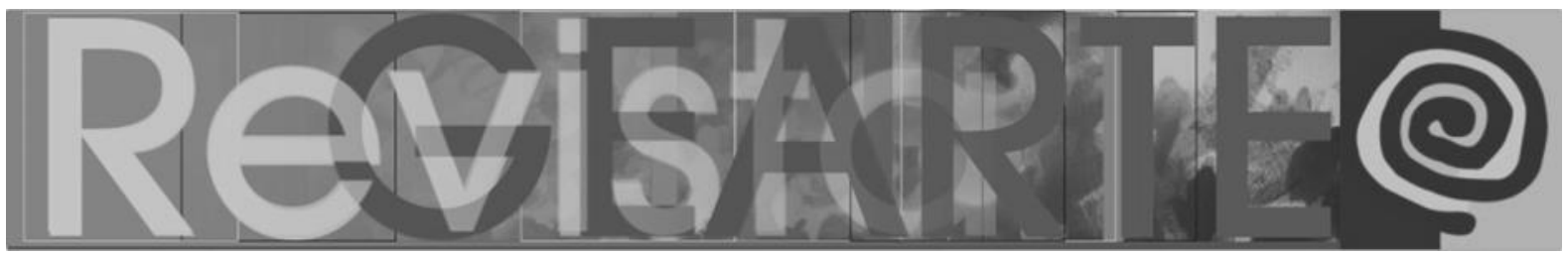

ATHAYDE, Sylvia. Flashes da vida cultural e artística na Bahia, nas décadas de 50 e 60. 2009. Disponível em: <https://leiamaisba.com.br/2009/10/20/flahes-da-vida-cultural-e-artistica-na-bahianas-decadas-de-50-e-60>. Acesso em: 06.07.2020.

AZEVEDO, Fernando Antônio Gonçalves; ARAÚJO, Clarissa Martins. Abordagem Triangular: leitura de imagens de diferentes códigos estéticos e culturais. Revista GEARTE, Porto Alegre, v. 2, n. 3, p. 345-358, dez. 2015. Disponível em: http://seer.ufrgs.br/gearte. Acesso em: 28.10.2019.

BALISCEI, João Paulo; TERUYA, Teresa Kazuko. Leitura e releitura de imagens: possibilidades de desenvolvimento de alfabetização visual crítica. In: XI CONGRESSO NACIONAL DE EDUCAÇÃO. Pontifícia Universidade Católica do Paraná. Curitiba, 23 a 26/09/2013. Disponível em: https://educere.bruc.com.br/CD2013/pdf/8478_5655.pdf. Acesso em: 06.07.2020

BARBOSA, Ana Mae Tavares Bastos. Arte-educação pós colonialista no Brasil: aprendizagem triangular. Comunicação \& Educação (2):59-64.1995. Disponível em: http://www.revistas.usp.br/ comueduc/article/view/36136. Acesso em: 18.07.2019.

BARBOSA, Ana Mae Tavares Bastos. A imagem no ensino de arte: anos oitenta e novos tempos. 9a Edição. São Paulo: Editora Perspectiva Ltda., 2014.

BARBOSA, Ana Mae Tavares Bastos. Arte/Educação ou Educação Artística na América Latina. In: QUEIROZ, João Paulo e OLIVEIRA, Ronaldo. Arte e ensino: propostas de resistência. Lisboa, D.L. 2018, 11-2. Repositório da Universidade de Lisboa. Disponível em: https://repositorio.ul.pt/bitstrea m/10451/37126/2/ULFBA_PE305_REDE_LIVRO_1_p12-21.pdf. Acesso em: 18.07.2019.

BRASIL. Ministério da Educação. Secretaria de Educação Fundamental. Parâmetros Curriculares Nacionais: Introdução aos Parâmetros Curriculares Nacionais. Brasília: MEC/SEF, 1997. Disponível em: <http://portal.mec.gov.br/seb/arquivos/pdf/livro01.pdf>. Acesso: 28.10.2019.

BRASIL. Secretaria de Educação Fundamental. Parâmetros curriculares nacionais: arte. Brasília: MEC/SEF, 1998. 116p. Disponível em: <http://portal.mec.gov.br/seb/arquivos/pdf/arte.pdf>. Acesso em: 28.10.2019

BRASIL. Secretaria de Educação Fundamental. Parâmetros Curriculares Nacionais Ensino Médio (PCNEM). Parte I: Bases Legais. 2000. Disponível em: <http://portal.mec.gov.br/seb/arqu ivos/pdf/blegais.pdf $>$. Acesso em: 28.10.2019

BRASIL. Secretaria de Educação Fundamental. Parâmetros Curriculares Nacionais Ensino Médio $(P C N)$. Parte II: Linguagens, códigos e suas tecnologias. 2000. Disponível em: <http://portal.mec. gov.br/seb/arquivos/pdf/14_24.pdf>. Acesso em: 28.10.2019.

BRASIL. Lei no 10.639, de 9 de janeiro de 2003. Altera a Lei no 9.394, de 20 de dezembro de 1996, que estabelece as diretrizes e bases da educação nacional, para incluir no currículo oficial da Rede de Ensino a obrigatoriedade da temática 'História e Cultura Afro-Brasileira', e dá outras providências. Diário Oficial da União, Brasília, 10 jan. 2003. Disponível em: < http://www.planalto.gov.br/ccivil_03/leis/2003/110.639.htm>. Acesso em dez. 2021.

EISNER, Elliot. O que pode a educação aprender das artes sobre a prática da educação? Currículo sem Fronteiras, v.8, n.2, pp.5-17, Jul/Dez 2008. ISSN 1645-1384 (online). Disponível em: http://www.curriculosemfronteiras.org/vol8iss2articles/eisner.pdf. Acesso em: 05.07.2020.

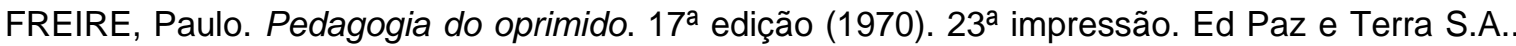
Rio de Janeiro. 1987.

FREIRE, Paulo. Criando métodos de pesquisa alternativa: aprendendo a fazê-lo melhor através da ação. In: BRANDÃO, Carlos Rodrigues (org.) Pesquisa participante. São Paulo: Brasiliense. 1996. p. 34-41.

FREIRE, Paulo. Pedagogia da autonomia: saberes necessários à prática educativa. 25a Edição. São Paulo: Paz e Terra, 1996. (Coleção Leitura). ISBN 85-219-0243-3. Disponível em: https://docero.com.br/doc/5nv0. Acesso em: 11.07.2020.

BRAZIL, Mariana; SOUZA, Marise Berta de. A obra artística fotográfica de Pierre Verger 855 em processos de ensino, aprendizagem e criação em artes no ensino médio.

Revista GEARTE, Porto Alegre, v. 8, n. 3, p. 831-857, set./dez. 2021.

Disponível em: http://seer.ufrgs.br/gearte 


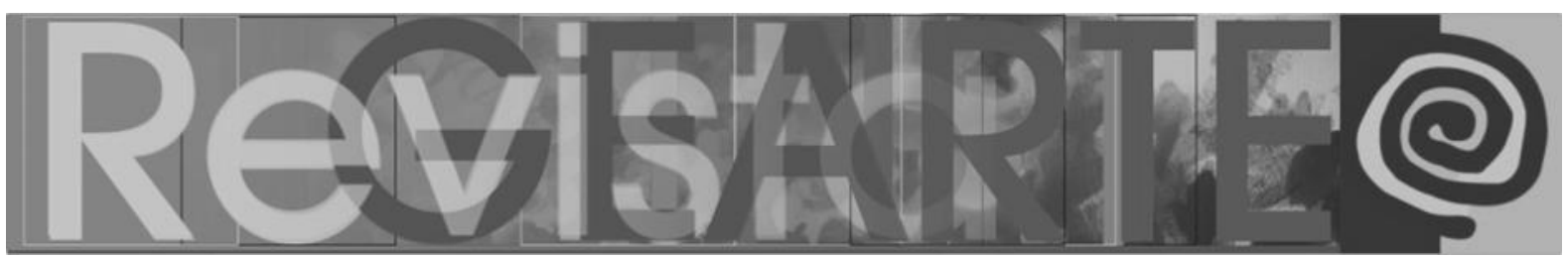

GAGLIANONE, Isabela. Pierre Verger, "50 anos de fotografia 1932-1982". Post publicado em Fotografia, Resenhas, marcado com a tag Pierre Verger em 03/09/2014. Disponível em: $<$ https://obenedito.com.br/pierre-verger-50-anos-fotografia/>. Acesso em: 22.01.2020.

HALL, Stuart. Cultural identity and cinematic representation. Framework, London, n. 36, p. 68-82. 1989. Disponível em: http://academic.uprm.edu/mleonard/theorydocs/readings/SHall.pdf. Acesso em: 18.07.2019.

HALL, Stuart. Quem precisa de identidade? In: SILVA, Tomaz Tadeu da (org.); HALL, Stuart; WOODWARD, Kathryn. Identidade e diferença: a perspectiva dos estudos culturais.15a ed. Petrópolis, RJ: Vozes, 2014 p.103-133.

HANSEN, Sheila de Oliveira. Reflexões sobre o ensino da arte no ensino médio: experiências de quem rema contra a maré. Rio de Janeiro: Fundação Oswaldo Cruz, 2017. 184 f. Dissertação (Mestrado Profissional em Educação Profissional em Saúde) - Programa de Pós-Graduação em Educação Profissional em Saúde. Escola Politécnica de Saúde Joaquim Venâncio. 2017.

LÜHNING, Angela. Pierre Fatumbi Verger e sua obra. Afro-Asia, Salvador, UFBA, 21-22 315-364, 1998. Disponível em: https://portalseer.ufba.br/index.php/afroasia/article/view/20971/13574. Acesso em: 29.07.2019.

MARTINI, Gerlaine Torres. A fotografia como instrumento de pesquisa na obra de Pierre Fatumbi Verger. Brasilia: Universidade de Brasília, 1999. (Dissertação de Mestrado) - Programa de Pósgraduação em Comunicação. Faculdade d Comunicação. Universidade de Brasília, Brasília, 1999. Disponível em: https://repositorio.unb.br/bitstream/10482/5104/1/1999_GerlaineTorresMartini.pdf. Acesso em: 01.07.2020.

MUNANGA, Kabengele. Entrevista de Kabengele Munanga - A difícil tarefa de definir quem é negro no Brasil. Estudos Avançados, São Paulo, Universidade de São Paulo, 18 (50): 51-56, 2004. Disponível em: http://www.scielo.br/pdf/ea/v18n50/a05v1850.pdf. Acesso em: 18.07.2019.

MUNANGA, Kabengele. Origens africanas do Brasil contemporâneo: histórias, línguas, culturas e civilizações. São Paulo: Global, 2009. 112 p. 2007.

MUNANGA, Kabengele. Histórias afro-atlânticas: algumas questões. In: Histórias afro-atlânticas ( vol 2) Antologia. PEDROSA, Adriano, CARNEIRO, Amanda, MESQUITA André (organização editorial). São Paulo: MASP, 2018. pg 604-605.

OSTROWER, Fayga. 2014. Criatividade e processos de criação. Petrópolis, Vozes, 2014.

PIERRE VERGER: chegar à Bahia, 5 de agosto 1946. Direção Carlos Pronzato. Brasil. Produtor: Bruno Delbechi. 2006. Diretor de fotografia: Stefano Barbi Cinti. Elenco: Alejandro Mariani, no papel de Verger. Video duração 9'44". Disponível em: https://www.youtube.com/watch?v=mi0G4JHjO7k. Acesso em: 29.07.2019.

QUINTERO Pablo, FIGUEIRA Patricia, ELIZALDE, Paz Concha. Uma breve história dos estudos decoloniais. In: MASP Afterall. Arte e descolonização. São Paulo, 2019, p.4 - 12. Disponível em: https://masp.org.br/uploads/temp/temp-6b4An9oil56DP0KVnRBC.pdf. Acesso em: 09.07.2019.

RISÉRIO, Antonio. Avant-garde na Bahia. São Paulo, Instituto Lina Bo e P.M.Bardi, 1995.

SONTAG, Susan. Sobre a fotografia. Tradução Rubens Figueiredo. 1a. Edição. São Paulo. 10a. Impressão. Companhia das Letras, 2004.

SOUTY, Jérôme. Em busca do olhar virgem: a propósito das fotografias de Pierre-Verger em torno do mundo, 1932-1946. Revista Poiésis, no 12: 209-221. 2008. Disponível em: https://periodicos.uff. br/poiesis/article/viewFile/26975/15679. Acesso em: 11.07.2020.

TAVARES, Luís Henrique Dias. História da Bahia. Editora UNESP. Salvador, Bahia. 10ª Edição (revista e ampliada). 542p. 2001. 


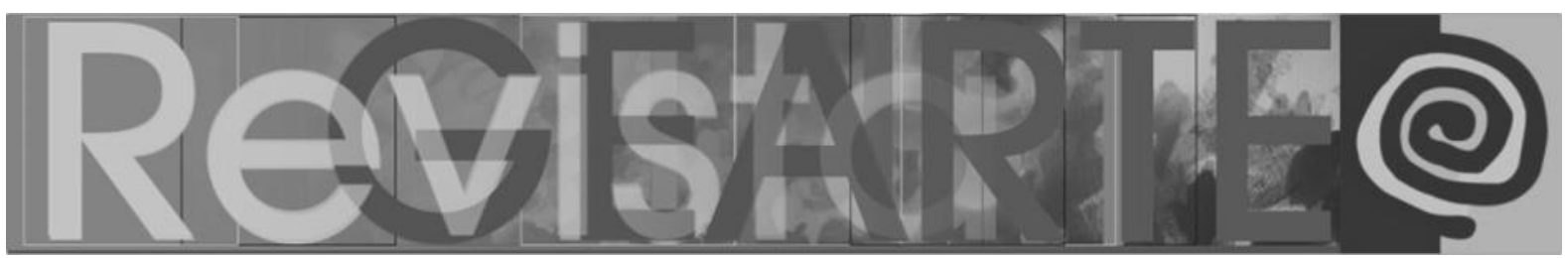

VERGER, Pierre. Retratos da Bahia. 1946 a 1952. Editora Currupio. 2a Edição. Salvador, Bahia. 1990.

WOLFENSON, Bob. Bob Wolfenson: cartas a um jovem fotógrafo. O mundo através das lentes. Elsevier, 2009. ISBN 978-85-352-2794-9. 223 pp.

WOODWARD, Katheryn. Identidade e diferença: uma introdução teórica e conceitual. In: SILVA, Tomaz Tadeu. 2014. Identidade e diferença: a perspectiva dos estudos culturais. Tomaz Tadeu da Silva (org.) Stuart Hall, Kathryn Woodward. 15a ed. Petrópolis, RJ: Vozes, 2014.

\section{Mariana Brazil}

Possui graduação em Licenciatura em Desenho e Plástica pela Universidade Federal da Bahia (2010), Especialização em Desenvolvimento Infantil e seus Transtornos (2012) e Mestrado em Artes Visuais pela Universidade Federal da Bahia e Universidade do Estado de Santa Catarina (UFBA/UDESC - 2020). Foi professora de Artes na educação infantil e fundamental da rede privada em Salvador e Lauro de Freitas, Bahia. Atualmente é professora de Artes Visuais no Ensino Médio da rede pública do Estado da Bahia. Tem experiência na área de arte-educação, com ênfase em Artes Plásticas, atuando principalmente nos seguintes temas: Processos de ensino/aprendizagem em artes, linguagens artísticas e Identidade cultural.

ORCID: http://orcid.org/0000-0003-4838-2530

E-mail: maribraz7@gmail.com

Currículo: http://lattes.cnpq.br/9182806977714256

\section{Marise Berta de Souza}

Possui graduação em Direito pela Universidade Católica do Salvador ( UCSal - 1977), mestrado em Artes Visuais pela Universidade Federal da Bahia (UFBA -1999) e doutorado em Artes Cênicas pela Universidade Federal da Bahia (2007). É professora Associada I do Instituto de Humanidades, Artes e Ciências Professor Milton Santos da Universidade Federal da Bahia (IHAC/UFBA). Docente Permanente do Mestrado Profissional em Artes. Produtora e realizadora audiovisual. Atua nas áreas de Comunicação e Artes, com ênfase em Cinema, tratando principalmente dos seguintes temas: cinema brasileiro, cultura brasileira e audiovisual.

ORCID: http://orcid.org/0000-0002-9133-4377

E-mail:mariseberta@uol.com.br

Currículo: http://lattes.cnpq.br/1962152440026381

Recebido em 19 de novembro de 2020

Aceito em 04 de maio de 2021 